\title{
Reviews and syntheses: An empirical spatiotemporal description of the global surface-atmosphere carbon fluxes: opportunities and data limitations
}

\author{
Jakob Zscheischler ${ }^{1,2}$, Miguel D. Mahecha ${ }^{2,3,4}$, Valerio Avitabile ${ }^{5}$, Leonardo Calle ${ }^{6}$, Nuno Carvalhais ${ }^{2,7}$, \\ Philippe Ciais $^{8}$, Fabian Gans ${ }^{2}$, Nicolas Gruber ${ }^{9}$, Jens Hartmann ${ }^{10}$, Martin Herold ${ }^{5}$, Kazuhito Ichii ${ }^{11,12}$, Martin Jung ${ }^{2}$, \\ Peter Landschützer ${ }^{9,13}$, Goulven G. Laruelle ${ }^{14}$, Ronny Lauerwald ${ }^{14,15}$, Dario Papale ${ }^{16}$, Philippe Peylin $^{7}$, \\ Benjamin Poulter ${ }^{6,17}$, Deepak Ray ${ }^{18}$, Pierre Regnier ${ }^{14}$, Christian Rödenbeck ${ }^{2}$, Rosa M. Roman-Cuesta ${ }^{5}$, \\ Christopher Schwalm ${ }^{19}$, Gianluca Tramontana ${ }^{16}$, Alexandra Tyukavina ${ }^{20}$, Riccardo Valentini ${ }^{21}$, Guido van der \\ Werf $^{22}$, Tristram O. West ${ }^{23}$, Julie E. Wolf ${ }^{23}$, and Markus Reichstein ${ }^{2,3,4}$ \\ ${ }^{1}$ Institute for Atmospheric and Climate Science, ETH Zurich, Universitätstr. 16, 8092 Zurich, Switzerland \\ ${ }^{2}$ Max Planck Institute for Biogeochemistry, Hans-Knöll-Str. 10, 07745 Jena, Germany \\ ${ }^{3}$ German Centre for Integrative Biodiversity Research (iDiv), Deutscher Platz 5e, 04103 Leipzig, Germany \\ ${ }^{4}$ Michael Stifel Center Jena for Data-Driven and Simulation Science, 07743 Jena, Germany \\ ${ }^{5}$ Wageningen University \& Research, Laboratory of Geo-Information Science and Remote Sensing, Droevendaalsesteeg 3, \\ 6708 PB Wageningen, the Netherlands \\ ${ }^{6}$ Institute on Ecosystems and Department of Ecology, Montana State University, Bozeman, MT 59717, USA \\ ${ }^{7}$ CENSE, Departamento de Ciências e Engenharia do Ambiente, Faculdade de Ciências e Tecnologia, \\ Universidade NOVA de Lisboa, Caparica, Portugal \\ ${ }^{8}$ Laboratoire des Sciences du Climat et de l'Environnement, CEA-CNRS-UVSQ, 91191, Gif sur Yvette, France \\ ${ }^{9}$ Institute of Biogeochemistry and Pollutant Dynamics, ETH Zurich, Zurich, Switzerland \\ ${ }^{10}$ Institute for Geology, CEN - Center for Earth System Research and Sustainability, University of Hamburg, Hamburg, \\ Germany 55, 20146 Hamburg, Germany \\ ${ }^{11}$ Department of Environmental Geochemical Cycle Research, Agency for Marine-Earth Science and Technology, \\ Yokohama, Japan \\ ${ }^{12}$ Center for Global Environmental Research, National Institute for Environmental Studies, Tsukuba, Japan \\ ${ }^{13}$ Max Planck Institute for Meteorology, Bundesstr. 53, Hamburg, Germany \\ ${ }^{14}$ Dept. Geoscience, Environment \& Society (DGES), CP160/02, Université Libre de Bruxelles, 1050 Brussels, Belgium \\ ${ }^{15}$ College of Engineering, Mathematics and Physical Sciences, University of Exeter, EX4 4QE Exeter, Devon, UK \\ ${ }^{16}$ Department for Innovation in Biological, Agro-food and Forest systems (DIBAF), University of Tuscia, \\ Viterbo, 01100, Italy \\ ${ }^{17}$ NASA Goddard Space Flight Center, Biospheric Sciences Laboratory, Greenbelt, MD 20771, USA \\ ${ }^{18}$ Institute on the Environment (IonE), University of Minnesota, Saint Paul, MN 55108, USA \\ ${ }^{19}$ Woods Hole Research Center, Falmouth MA 02540, USA \\ ${ }^{20}$ Department of Geographical Sciences, University of Maryland, College Park, MD, USA \\ ${ }^{21}$ CMCC, Via A. Imperatore, 16, 73100, Lecce, Italy \\ ${ }^{22}$ Faculty of Earth and Life Sciences, Vrije Universiteit Amsterdam, Amsterdam, the Netherlands \\ ${ }^{23}$ Joint Global Change Research Institute, Pacific Northwest National Laboratory, College Park, MD, USA
}

Correspondence to: Jakob Zscheischler (jakob.zscheischler@env.ethz.ch) and Miguel D. Mahecha (mmahecha@bgc-jena.mpg.de)

Received: 8 October 2016 - Discussion started: 20 October 2016

Revised: 6 June 2017 - Accepted: 28 June 2017 - Published: 9 August 2017

Published by Copernicus Publications on behalf of the European Geosciences Union. 
Abstract. Understanding the global carbon (C) cycle is of crucial importance to map current and future climate dynamics relative to global environmental change. A full characterization of $\mathrm{C}$ cycling requires detailed information on spatiotemporal patterns of surface-atmosphere fluxes. However, relevant $\mathrm{C}$ cycle observations are highly variable in their coverage and reporting standards. Especially problematic is the lack of integration of the carbon dioxide $\left(\mathrm{CO}_{2}\right)$ exchange of the ocean, inland freshwaters and the land surface with the atmosphere. Here we adopt a data-driven approach to synthesize a wide range of observation-based spatially explicit surface-atmosphere $\mathrm{CO}_{2}$ fluxes from 2001 to 2010 , to identify the state of today's observational opportunities and data limitations. The considered fluxes include net exchange of open oceans, continental shelves, estuaries, rivers, and lakes, as well as $\mathrm{CO}_{2}$ fluxes related to net ecosystem productivity, fire emissions, loss of tropical aboveground $\mathrm{C}$, harvested wood and crops, as well as fossil fuel and cement emissions. Spatially explicit $\mathrm{CO}_{2}$ fluxes are obtained through geostatistical and/or remote-sensing-based upscaling, thereby minimizing biophysical or biogeochemical assumptions encoded in process-based models. We estimate a bottom-up net C exchange (NCE) between the surface (land, ocean, and coastal areas) and the atmosphere. Though we provide also global estimates, the primary goal of this study is to identify key uncertainties and observational shortcomings that need to be prioritized in the expansion of in situ observatories. Uncertainties for NCE and its components are derived using resampling. In many regions, our NCE estimates agree well with independent estimates from other sources such as processbased models and atmospheric inversions. This holds for Europe (mean $\pm 1 \mathrm{SD}: 0.8 \pm 0.1 \mathrm{PgC} \mathrm{yr}^{-1}$, positive numbers are sources to the atmosphere), Russia $\left(0.1 \pm 0.4 \mathrm{PgC} \mathrm{yr}^{-1}\right)$, East Asia $\left(1.6 \pm 0.3 \mathrm{PgC} \mathrm{yr}^{-1}\right)$, South Asia $\left(0.3 \pm 0.1 \mathrm{PgC} \mathrm{yr}^{-1}\right)$, Australia $\left(0.2 \pm 0.3 \mathrm{PgC} \mathrm{yr}^{-1}\right)$, and most of the Ocean regions. Our NCE estimates give a likely too large $\mathrm{CO}_{2}$ sink in tropical areas such as the Amazon, Congo, and Indonesia. Overall, and because of the overestimated $\mathrm{CO}_{2}$ uptake in tropical lands, our global bottom-up NCE amounts to a net sink of $-5.4 \pm 2.0 \mathrm{PgC} \mathrm{yr}^{-1}$. By contrast, the accurately measured mean atmospheric growth rate of $\mathrm{CO}_{2}$ over 20012010 indicates that the true value of $\mathrm{NCE}$ is a net $\mathrm{CO}_{2}$ source of $4.3 \pm 0.1 \mathrm{PgC} \mathrm{yr}^{-1}$. This mismatch of nearly $10 \mathrm{PgC} \mathrm{yr}^{-1}$ highlights observational gaps and limitations of data-driven models in tropical lands, but also in North America. Our uncertainty assessment provides the basis for setting priority regions where to increase carbon observations in the future. High on the priority list are tropical land regions, which suffer from a lack of in situ observations. Second, extensive $p \mathrm{CO}_{2}$ data are missing in the Southern Ocean. Third, we lack observations that could enable seasonal estimates of shelf, estuary, and inland water-atmosphere $\mathrm{C}$ exchange. Our consistent derivation of data uncertainties could serve as prior knowledge in multicriteria optimization such as the Carbon Cycle Data Assimilation System (CCDAS) and atmospheric inversions, without over- or under-stating bottomup data credibility. In the future, NCE estimates of carbon sinks could be aggregated at national scale to compare with the official national inventories of $\mathrm{CO}_{2}$ fluxes in the land use, land use change, and forestry sector, upon which future emission reductions are proposed.

\section{Introduction}

The global carbon (C) cycle is crucial for sustaining life on Earth (Vernadsky, 1926). Humans have largely modified the C cycle over centuries if not millennia (Ruddiman, 2003; Pongratz et al., 2009). In the Industrial Era, the humancaused perturbation of the $\mathrm{C}$ cycle is largely driven by emissions of $\mathrm{CO}_{2}$ from burning fossil fuel $\mathrm{C}$ previously stored in geological deposits, and changes in land use, which transfer $\mathrm{CO}_{2}$ from $\mathrm{C}$ stocks in the land biosphere to the atmosphere, but can also result into $\mathrm{CO}_{2}$ removal and increase of land stocks. As those anthropogenic $\mathrm{C}$ emissions are partly taken up by oceans and terrestrial ecosystems not affected by land use change, the different reservoirs of the global $\mathrm{C}$ cycle and the fluxes between them change over time (Houghton, 2007). A precise knowledge of the various stocks and fluxes in the $\mathrm{C}$ cycle is a prerequisite to monitor these changes and make well-informed predictions under future climate change.

The Global Carbon Project (GCP) has made major efforts in this direction and its annual updates of the global $\mathrm{C}$ budget have become a key source of information for the scientific community and policy makers (Le Quéré et al., 2015). The GCP annual C budget quantifies the partitioning of anthropogenic $\mathrm{C}$ emissions among the atmosphere, land, and ocean components of the global $\mathrm{C}$ cycle, and separates the net land flux into land use change emissions and a so-called "residual land C sink" obtained by difference with other terms of the budget and thus corresponding to the net land-atmosphere $\mathrm{CO}_{2}$ flux over non-land-use affected ecosystems. The budget of the GCP focuses on annual values integrated at the global scale. An important point is that the GCP budget quantifies solely the anthropogenic perturbation of $\mathrm{CO}_{2}$ fluxes, i.e. it provides information about the fate of anthropogenic $\mathrm{CO}_{2}$ emissions in natural reservoirs (Ciais et al., 2013). According to the GCP, during the years 2000-2009 about $45 \%$ of the anthropogenic $\mathrm{CO}_{2}$ emissions each year stay in the atmosphere, the rest being taken up by the oceans (27\%) and land (27\%) (Le Quéré et al., 2015).

Recently, a case has been made for a globally policyrelevant integrated $\mathrm{C}$ observation and analysis system (Ciais et al., 2014). This system would go beyond the update of global budgets, for which the $\mathrm{CO}_{2}$ growth rate accurately measured at a single station (e.g. Mauna Loa) is sufficient 
to constrain the global annual time-space integral of all $\mathrm{CO}_{2}$ sources and sinks. It proposes to quantify regional $\mathrm{CO}_{2}$ fluxes with sufficient spatial details to monitor the effectiveness of $\mathrm{CO}_{2}$ mitigation and to detect and monitor trends of $\mathrm{CO}_{2}$ losses and gains by land and terrestrial systems. This is partly relevant for monitoring country-level intended nationally determined contributions (INDCs) to incept a $\mathrm{CO}_{2}$ emission trajectory consistent with global warming below $2{ }^{\circ} \mathrm{C}$ (UNFCCC, 2015). In such a policy-relevant $C$ observing system, an uncertainty assessment for each data stream of $\mathrm{CO}_{2}$ fluxes at different spatial and temporal scales is important to, for instance, identify significant regional emission hotspots and trends in emissions and sinks (Ciais et al., 2014).

The steadily increasing number of Earth observations, in particular since the start of the satellite era, has improved our knowledge of the Earth system (Berger et al., 2012; Tatem et al., 2008). Especially C cycle science has benefited from globally available satellite observations and community efforts to unify in situ observational networks such as FLUXNET on land (Baldocchi, 2014), the Surface Ocean $\mathrm{CO}_{2}$ Atlas (SOCAT) (Bakker et al., 2014), and more recently $\mathrm{CO}_{2}$ outgassing from lakes and rivers (Raymond et al., 2013). Combining these available point measurements of either $\mathrm{CO}_{2}$ fluxes (e.g. from eddy covariance towers on land), or variables that can be directly related to $\mathrm{CO}_{2}$ fluxes (e.g. $p \mathrm{CO}_{2}$ over aquatic surfaces) with climate fields and remotely sensed variables (e.g. vegetation greenness), provides a basis to robustly upscale surface-atmosphere $\mathrm{CO}_{2}$ exchange to larger areas using statistical models (Jung et al., 2011; Rödenbeck et al., 2015).

In this study we aim at characterizing the ability of current $\mathrm{C}$ cycle observations on ground for quantifying a spatiotemporally explicit picture of the net $\mathrm{CO}_{2}$ exchange between the Earth's surface (terrestrial and aquatic) and the atmosphere (NCE). Unlike the GCP global budget of anthropogenic $\mathrm{CO}_{2}$, we consider here the full contemporary net exchange of surface-atmosphere $\mathrm{CO}_{2}$ fluxes. We focus our analysis on fluxes that can be directly derived from observations. That is, we use data-driven empirical models instead of process-based models that are only indirectly constrained by observations. Further, we only consider "bottom-up" estimates derived from measurements at the Earth's surface or from satellites. Inversions, which largely rely on atmospheric measurements in combination with a transport model, are not directly included but used for comparison. The goal of this analysis is to test the up-scaling of local flux-related observations to regional and global budgets, and point out the limitations of the current observational networks and data-driven models used to interpolate point-scale $\mathrm{CO}_{2}$ fluxes across larger scales, for quantifying the most important $\mathrm{CO}_{2}$ fluxes exchanged between the Earth's surface and the atmosphere.

One of the major innovations of this study is combining data-driven estimates of oceanic, inland waters, and terrestrial ecosystems $\mathrm{CO}_{2}$ exchange and providing spatially explicit maps of the $\mathrm{CO}_{2}$ exchange between the surface and the atmosphere at a monthly scale for the decade 2001-2010. At the same time, by adding emissions from fossil fuels and cement production and comparing with the annual growth rate of $\mathrm{CO}_{2}$, we identify the limits of a $\mathrm{C}$ budget purely driven by surface data. We characterize regions in which surfaceatmosphere $\mathrm{CO}_{2}$ fluxes are most uncertain based on the currently available data and the models used for upscaling, and thus point out regions where either more observations or a better understanding of the processes are necessary. It is not the primary goal of this study to provide the best global $\mathrm{CO}_{2}$ flux inventory, but rather to identify the key uncertainties and observational shortcomings that need to be prioritized in the expansion of in situ observatories.

The paper is structured as follows. In Sect. 2 we introduce the different data streams used in the analysis, including spatially explicit estimates of aquatic and terrestrial $\mathrm{CO}_{2} \mathrm{ex}-$ change. In Sect. 3 we present the resulting combined synthesis as global maps, regionally aggregated fluxes, absolute and relative uncertainties, latitudinal averages and seasonal cycles. Section 4 addresses the benefits and limits of the current observational system for constraining global net $\mathrm{CO}_{2}$ fluxes. Section 5 summarizes the main conclusions drawn from this synthesis.

\section{Data and methods}

We collected ensembles of data-driven estimates of the NCE for the major subsystems of the Earth from 2001 to 2010 (Table 1). Each data set was aggregated to $1 \times 1^{\circ}$ spatial resolution. All data sets have an original spatial resolution of at least $1 \times 1^{\circ}$ and were aggregated to the lower-resolution common grid. The temporal resolution is monthly. For data sets that were only available at yearly timescale or once over the complete time period (Table 1), we distributed fluxes evenly across all months. In this synthesis, we include NCE from open oceans, continental shelves, estuaries, rivers, lakes, and terrestrial ecosystems, which we combine with estimates of fossil fuel and cement emissions (FF). The terrestrial ecosystem component accounts for fire emissions (Fire), loss of tropical above-ground biomass assumed to be released as $\mathrm{CO}_{2}$ to the atmosphere $\left(E_{\mathrm{LUC}}\right)$, emissions of the $\mathrm{CO}_{2}$ contained in harvested wood (Wood) and crops (Crops), and net ecosystem productivity (NEP). We combine fluxes from oceans, shelves, and estuaries into a homogeneous marine flux product in order to account for overlapping or missing regions from the different aquatic products (Marine, Sect. 2.2.6). We further compare the net $\mathrm{CO}_{2}$ exchange (NCE) derived from the combination of all the above products with the growth rate of atmospheric $\mathrm{CO}_{2}$ (CGR). Combining all fluxes, the overall NCE between the Earth's surface and the atmosphere is given as

$$
\begin{aligned}
\mathrm{NCE} & =\text { Marine }+ \text { Lakes }+ \text { Rivers }-\mathrm{NEP} \\
& + \text { Crops }+ \text { Wood }+E_{\mathrm{LUC}}+\text { Fire }+ \text { FF } .
\end{aligned}
$$


Table 1. Data sets used in this study including reference, time period and number of ensemble runs. If not specified, temporal resolution is monthly.

\begin{tabular}{|c|c|c|c|}
\hline Data set & Reference & Time period used & No. runs \\
\hline Ocean & $\begin{array}{l}\text { Landschützer et al. (2014) } \\
\text { Rödenbeck et al. (2014) }\end{array}$ & 2001-2010 & $5+5=10$ \\
\hline Shelf & Laruelle et al. (2014) & 1 estimate & 1 \\
\hline Estuaries & Laruelle et al. (2013) & 1 estimate & 1 \\
\hline Marine & & 2001-2010 & 10 \\
\hline Rivers & Lauerwald et al. (2015) & 1 estimate & 50 \\
\hline Lakes & Raymond et al. (2013) & 1 estimate & 1 \\
\hline NEP & Tramontana et al. (2016) & 2001-2010 & 8 \\
\hline Crops & Wolf et al. (2015b) & 2001-2010, annual & 10 \\
\hline Wood & Poulter (2015) & 2000, 1 estimate & 1 \\
\hline Fire & Giglio et al. (2013) & $2001-2010$ & 1 \\
\hline \multirow[t]{2}{*}{$E_{\mathrm{LUC}}$} & Tyukavina et al. (2015) & 2000-2012, 1 estimate & $1+1=2$ \\
\hline & Harris et al. (2012) & 2000-2005, 1 estimate & \\
\hline FF (fossil fuels) & CARBONES & $2001-2010$ & 1 \\
\hline Atmospheric growth rate & NOAA & 2001-2010 & 1 \\
\hline
\end{tabular}

All units were transformed into fluxes of $\mathrm{C}$ per unit time. If all $\mathrm{CO}_{2}$ fluxes were included, NCE would translate into the CGR. By convention negative fluxes indicate an uptake by the Earth surface. Data scarcity precludes including all known vertical $\mathrm{CO}_{2}$ fluxes in this study. Missing fluxes include geological $\mathrm{CO}_{2}$ fluxes, erosion-related fluxes, non$\mathrm{CO}_{2}$ fluxes, wood product pools decay, and biofuel burning.

\subsection{Uncertainty estimation and propagation}

For five of the nine variables contributing to the NCE of Eq. (1), we obtained multiple spatiotemporally explicit estimates directly from the raw data products. These estimates are expected to sample the uncertainty in each variable. We could obtain 10 different estimates for the terms Marine and Crops respectively, 50 estimates for Rivers, eight estimates for NEP, two estimates for $E_{\mathrm{LUC}}$, and only one estimate for each of the remaining four variables (Table 1). To estimate NCE including spatiotemporally explicit uncertainties, we randomly draw ensemble members from each of these nine terms to create an integrated ensemble for NCE (Eq. 1). With the available estimates, we could in principle create $10 \times 50 \times 8 \times 10 \times 2=80000$ spatiotemporal explicit estimates of NCE. From these 80000 possible NCE estimates we randomly select 200 (to reduce computational expense) to construct the NCE ensemble, which is used in the remainder of the paper. This resampling approach is illustrated in Fig. 1 and ensures a consistent propagation of spatiotemporally correlated uncertainties. For instance, by aggregating each member of NCE to the desired region and estimating uncertainty through the 200 members, we can compute regional uncertainties. In addition, we computed mean fluxes, uncertainty (defined as 1 standard deviation (SD) of the annual mean across all realizations), interannual variability (IAV, defined here as $1 \mathrm{SD}$ of annual means across all available years) and the coefficient of variation $(\mathrm{CV}=\mathrm{IAV} /$ mean $)$ for each of the nine flux terms in Eq. (1).

\subsection{Aquatic fluxes}

\subsubsection{Oceans}

For the global open ocean flux estimate we used two complementary data-driven estimates (Table 1). Both approaches computed maps of the sea surface partial pressure of $\mathrm{CO}_{2}$ $\left(p \mathrm{CO}_{2}\right)$. They relied on the surface ocean $\mathrm{CO}_{2}$ observations from the SOCATv2 database (Bakker et al., 2014) and filled data gaps by either establishing relationships between auxiliary driver data and observations, which can then be applied to extrapolate $p \mathrm{CO}_{2}$ in regions without data coverage (SOM-FFN; Landschützer et al., 2014), or by assimilating the available observations in a mass-balance model of the mixed layer and directly interpolating data gaps (Jena CarboScope mixed-layer scheme oc_v1.2; Rödenbeck et al., 2014). To test the established predictor-target relationship, the SOM-FFN method holds back a certain fraction of the observations proportional to the method's degrees of freedom for internal validation. Repeating this relationship building process and withholding different sets of validation data has created the five ensemble members used for this study. For the Jena CarboScope mixed-layer scheme, we used the five sensitivity cases with varied parameters such as changes in correlation length as described in Rödenbeck et al. (2014).

The $p \mathrm{CO}_{2}$ fields of both methods have been validated against independent observations (Landschützer et al., 2014, 2015; Rödenbeck et al., 2014) and were compared with other complementary data-based interpolation methods (Rödenbeck et al., 2015), illustrating their good performance in reconstructing interannual variation. 


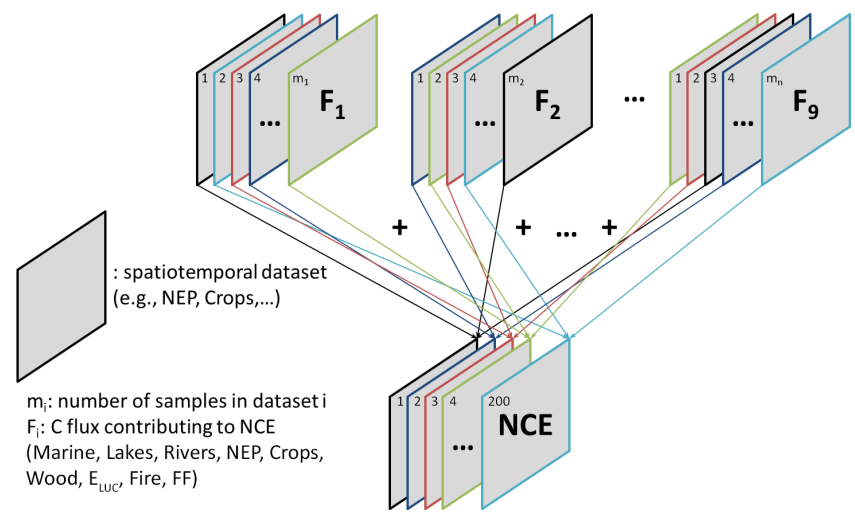

Figure 1. Schematic explanation of the uncertainty propagation. Each spatiotemporal estimate of NCE is computed as the sum of randomly selected estimates of the nine fluxes contributing to NCE (see Eq. 1, here denoted by $F_{i}$ ). For this study we compute 200 estimates of NCE. Uncertainties can be assessed at different spatial scales by first aggregating all NCE estimates to the desired scale and then using the 200 members for uncertainty estimation.

Both methods calculate the air-sea flux using a bulk formulation of the air-sea $\mathrm{CO}_{2}$ transfer, driven by the airsea $p \mathrm{CO}_{2}$ difference $\left(\triangle p \mathrm{CO}_{2}\right)$ (Jähne et al., 1987) and a quadratic dependence of the wind speed at a height of $10 \mathrm{~m}$ (Wanninkhof, 1992) updating the gas transfer coefficient to fit a mean transfer velocity of $16 \mathrm{~cm}$ per hour following Wanninkhof (2013). High-resolution wind speeds at $10 \mathrm{~m}$ are calculated from the $u$ and $v$ wind components of the ERA-Interim wind speed analysis (Dee et al., 2011) and atmospheric $p \mathrm{CO} 2$ fields, required to calculate the $\triangle p \mathrm{CO}_{2}$, are calculated are estimated from the GLOBALVIEW-CO2 (2012) marine boundary layer $\mathrm{CO}_{2}$ product.

\subsubsection{Shelves}

For continental shelf seas we derived the $\Delta p \mathrm{CO}_{2}$ from $3 \times 10^{6}$ surface $p \mathrm{CO} 2$ measurements extracted from the SOCATv2 database (Bakker et al., 2014) and observational atmospheric $p \mathrm{CO}_{2}$ data (GLOBALVIEW-CO2, 2012). The local $\mathrm{CO}_{2}$ air-sea flux values were then obtained using a winddependent quadratic formulation parameterized as in Wanninkhof et al. (2013) and wind speeds extracted from a crosscalibrated multiplatform (CCMP) high-resolution data product for ocean surface winds (Atlas et al., 2011). The resulting local fluxes were then integrated spatially over 150 coastal regions (COSCATs - COastal Segmentation and related CATchments; Laruelle et al., 2013; Meybeck et al., 2006) using distinct integration methods depending on the data density (Laruelle et al., 2014). In addition, a temporal integration was also performed at the monthly, seasonal, or yearly timescale depending on the data coverage. These temporally and regionally averaged air-sea $\mathrm{CO}_{2}$ fluxes were then disaggregated using a $1^{\circ}$ resolution map excluding land areas and open ocean waters using the shelf break as outer limit (Laruelle et al., 2014).

\subsubsection{Estuaries}

The $\mathrm{CO}_{2}$ emissions from estuaries were derived from 161 annually averaged local $\mathrm{CO}_{2}$ air-water exchange rates reported in the literature (Laruelle et al., 2013). The data were allocated to one of the 45 coastal MARCATS regions (MARgins and CATchments Segmentation) defined in Laruelle et al. (2013) and further categorized among the four dominant estuarine types (i.e. small deltas, tidal systems, lagoons, fjords; see Dürr et al., 2011) to calculate regionally averaged, type-specific $\mathrm{CO}_{2}$ emission rates. In MARCATS regions devoid of estuarine data, the global average type-dependent airwater $\mathrm{CO}_{2}$ flux was used from Laruelle et al. (2013). These flux densities were then multiplied by the estuarine surface areas for each type, estimated at $1^{\circ}$ resolution from the length of the coastline and a type-specific length to estuarine surface ratio (Dürr et al., 2011).

\subsubsection{Marine}

We created 10 marine estimates by combining the 10 estimates for the open oceans with shelves and estuaries to a consistent marine product. For pixels with observations from multiple products (e.g. estuaries and oceans) we follow a "priority rule" whereby the shelves, estuaries, or oceans observation value only (in that order) is retained. Empty pixels are gap-filled with a $3 \times 3$ mean window. This same filter is also applied to the rest of the merged data set to smooth out hard borders between the different estimates. This application does not significantly change the overall flux estimates, but arguably results in a more realistic interface. Note that in the merged Marine product, uncertainty and IAV could only be assessed for the ocean flux.

\subsubsection{Rivers}

Fifty estimates of $\mathrm{CO}_{2}$ evasion from streams and rivers were derived from a spatially explicit, empirical model of river water $p \mathrm{CO}_{2}$ and global maps of stream surface areas and gas exchange velocities at a resolution of $0.5^{\circ}$ (Lauerwald et al., 2015). The empirical $p \mathrm{CO}_{2}$ model was trained on 1182 river catchments from the GLORICH database (Hartmann et al., 2014) for which averages of $p \mathrm{CO}_{2}$ could be calculated. Steepness of terrain, terrestrial net primary production, average air temperature, as well as population density were identified as predictors $\left(R^{2}=0.47\right)$. The global maps of stream surface area and gas exchange velocities were obtained by a GIS-based application of published empirical scaling laws (Raymond et al., 2012, 2013) using topography (Lehner et al., 2008) and runoff (Fekete et al., 2002). The $\mathrm{CO}_{2}$ evasion was calculated as product of water-air $p \mathrm{CO}_{2}$ gradient (assuming an atmospheric $p \mathrm{CO}_{2}$ of $390 \mu \mathrm{atm}$ ), river surface areas, and gas exchange velocities. A Monte Carlo simula- 
tion based on standard errors of the predictors in the $p \mathrm{CO}_{2}$ model and uncertainty ranges for estimates of stream surface area and gas exchange velocity was run to produce $50 \mathrm{CO}_{2}$ evasion estimates.

\subsubsection{Lakes}

Estimates of $\mathrm{CO}_{2}$ evasion from lakes and reservoirs were taken from Raymond et al. (2013), which reports average lake $p \mathrm{CO}_{2}$, total lake/reservoir surface area, and total $\mathrm{CO}_{2}$ evasion for 231 COSCAT regions (including endorheic regions). For the total lake/reservoirs surface area, data from the Global Lakes and Wetland Database (GLWD; Lehner and Döll, 2004) were combined with an estimate for small lakes and reservoirs not represented in the GLWD using a scaling law. Here, we used the GLWD data to downscale the estimates of Raymond et al. (2013) to a continuous $1^{\circ}$ resolution. For this purpose, we combined a uniform air-water $\mathrm{CO}_{2}$ flux (per unit surface area) within each COSCAT region with a spatially explicit estimate of the lakes/reservoirs surface at this resolution. The small lakes/reservoirs not represented in the GLWD were assumed evenly distributed over the COSCAT area.

\subsection{Terrestrial fluxes}

\subsubsection{NEP}

We used eight empirical, machine learning based products from FLUXCOM (www.fluxcom.org) for net ecosystem productivity (NEP), derived from more than 200 FLUXNET sites and exclusively remote-sensing-based predictor variables ("FLUXCOM-RS"; see Tramontana et al., 2016). The eight machine learning methods used here include artificial neural networks, four variants of model or regression tree ensembles, kernel methods (support vector machines, kernel ridge regression), and multivariate adaptive regression splines (Tramontana et al., 2016). All methods were trained on 8-daily tower-based NEP estimates.

\subsubsection{Crops}

About $42 \%$ of global crop biomass is harvested, transported, and respired offsite (Wolf et al., 2015a). The impact of this lateral $\mathrm{C}$ transport on fluxes can be seen at the country scale in the form of import and exports, but even more so at subregional scales where the movement of crop biomass to feed livestock and humans is evident (Hayes et al., 2012; West et al., 2011). To capture the spatial distribution of $\mathrm{CO}_{2}$ fluxes from agricultural harvest, we used livestock and human $\mathrm{CO}_{2}$ emissions estimates (Wolf et al., 2015b) that are available from 2005 to 2011 at $0.05^{\circ}$ spatial resolution. $\mathrm{CO}_{2}$ that has previously been taken up from the atmosphere by the harvested biomass of crops is included in the NEP estimates from FLUXCOM. We aggregated best estimates of the data to $1^{\circ}$, added all uncertainty estimates within one $1^{\circ}$ pixel and used them as estimates for 1 standard deviation on the new $1^{\circ}$ grid. Assuming Gaussian-distributed errors we sampled 1000 values at each pixel and used 10 maps of the 5 th, 15 th, $\ldots, 95$ th quantiles as different ensemble members. Data were then linearly extrapolated back to 2001-2004. In a final step, and because it is not known in which months the emissions occur, we further distributed the annual estimates equally across all 12 months.

\subsubsection{Wood}

We used one estimate of globally gridded forest harvesting data around year 2000 as described in the Supplement S1. These data include fuelwood and roundwood harvested volumes in $\mathrm{m}^{3}$. We translated wood volumes into units of C using a value of $0.275 \mathrm{MgC} \mathrm{m}^{-3}$ from FAO (http://www.fao. org/docrep/w4095e/w4095e06.htm), assuming wood density of $0.55 \mathrm{t} \mathrm{m}^{-3}$. To avoid double counting wood harvest with aboveground biomass loss in tropical areas exposed to land use change, we use wood harvesting data only in locations where the amount of harvested wood (in C) exceeds $E_{\text {LUC }}$ (Sect. 2.3.4). We assume that $100 \%$ of the harvested wood is respired back to the atmosphere within a year, thus assuming no change in $\mathrm{C}$ stock of wood products and constant harvesting rates across years. However, $\mathrm{C}$ contained in harvested wood is usually emitted at a different location than where the harvest took place. We thus incorporated lateral shifts of harvested wood by redistributing wood harvest according to the consumption of wood as explained in the Supplement (see also Fig. S2).

\subsection{4 $\quad E_{\mathrm{LUC}}$}

We used two estimates for $\mathrm{CO}_{2}$ fluxes due to tropical deforestation and degradation. It is assumed here that $100 \%$ of biomass loss is converted to a $\mathrm{CO}_{2}$ flux being released instantly (within a year) to the atmosphere. In reality, a fraction of lost tropical biomass decays in ecosystems (belowground biomass and slash) and a fraction is used in wood products of various lifetime. However, slash is decomposed fast and biomass from deforested areas is transformed on average to short-lived products ( $\approx 5$ years after Earles et al., 2012).

1. Gross tropical deforestation emissions were taken from Harris et al. (2012). They represent total (above- and belowground) $\mathrm{C}$ loss from gross forest cover loss in the tropical regions due to human or natural causes (e.g. disturbances without forest recovery) for the period of 2000-2005.

2. More recent estimates of aboveground $\mathrm{C}$ loss in the tropics from stand-replacement disturbance of forest cover due to human or natural causes were provided by Tyukavina et al. (2015). Sample-based estimates of mean 2000-2012 aboveground C loss for each $30 \mathrm{~m}$ resolution forest $\mathrm{C}$ stratum were attributed to all pixels of 


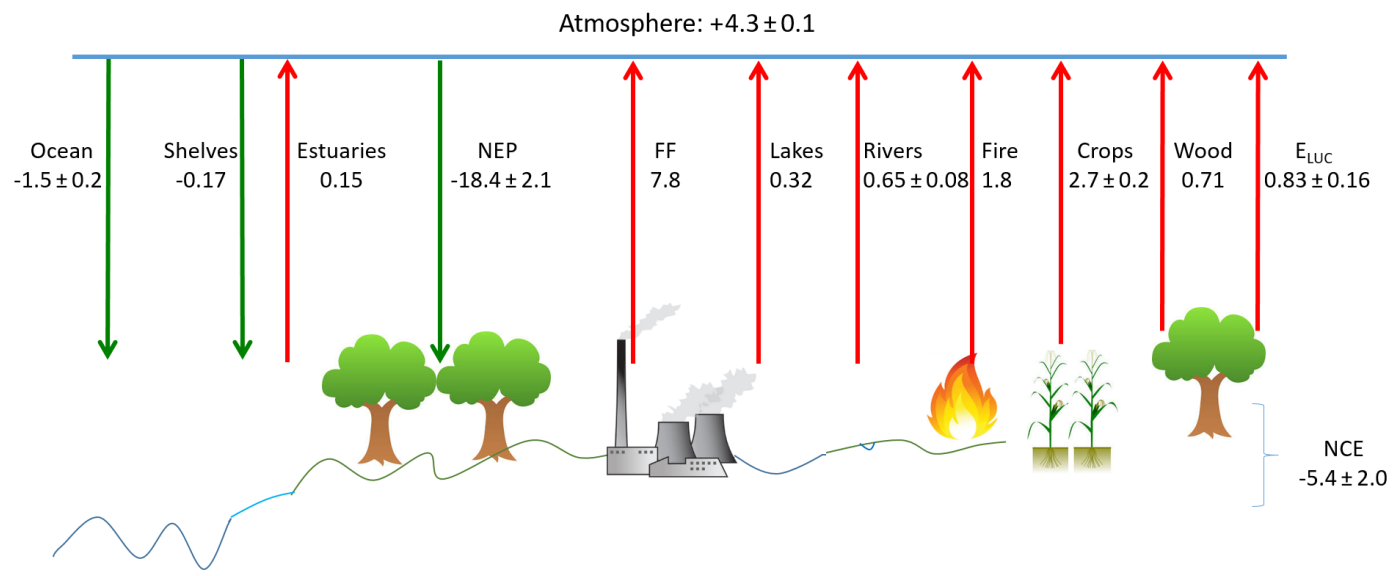

Figure 2. Different components of observation-driven $\mathrm{C}$ exchange between the Earth's surface and the atmosphere. Red arrows denote a flux from the surface to the atmosphere (net source), green arrows denote a flux from the atmosphere to the surface (net sink). Units are in

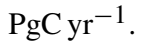

the corresponding stratum and averaged to the $1 \times 1^{\circ}$ resolution.

We used $E_{\mathrm{LUC}}$ only in those pixels where the average of the two estimates (1 and 2) exceeds wood harvesting (Sect. 2.3.3).

\subsubsection{Fire}

We used fire emissions from the Global Fire Emissions Database version 4 with small fires (GFED4s, http://www. globalfiredata.org) based on burned area from Giglio et al. (2013) and Randerson et al. (2012) and an updated version of the biogeochemical modelling framework of van der Werf et al. (2010) to convert burned area to C emissions. We included all fire types except tropical deforestation and degradation fires, which are included in $E_{\mathrm{LUC}}$ and should thus not be counted twice (Sect. 2.3.4). For an earlier version of fire emissions (GFED3) a Monte Carlo simulation indicated an uncertainty of about $20 \%$ (1SD) for continentalscale estimates but these estimates turned out to be not very reliable (van der Werf et al., 2017). For example, the inclusion of small fire burned area led to an increase in burned area exceeding the previously assumed uncertainty and the current version therefore has no uncertainty assessment at pixel level. Note that GFED fire emissions depend on estimates of net primary production and combustion factors as computed by the CASA model.

\subsubsection{FF}

We use the IER-EDGARv4.2 product for fossil fuel and cement emissions, which was derived within the CARBONES project by the Institute für Energiewirtschaft und Rationelle Energieanwendung (IER). It is based on the Edgar v4.2 fossil fuel spatial distribution (with the highest spatial resolution of $0.1 \times 0.1^{\circ}$ ) and uses national consumption and global production statistics. Based on the sectorial distinguished EDGARv4.2 emissions, sector-specific and country-specific temporal profiles were included. A detailed description of the construction of the product is given at http://www.carbones. eu/wcmqs/project/ccdas/\#Fossil_Fuel. It is important to note that FF emissions here are not observation based as the IEREDGARv4.2 product is partly based on national estimates from official inventories reported by countries to the UNFCCC.

\subsection{Atmospheric growth rate}

We used the atmospheric rate of change of $\mathrm{CO}_{2}$, which is equal to the space and time integral of all emissions and sinks at the surface, using the calculations made by the GCP (Le Quéré et al., 2015). These calculations are based on the global growth rate of atmospheric $\mathrm{CO}_{2}$ (CGR) provided by the US National Oceanic and Atmospheric Administration Earth System Research Laboratory (NOAA/ESRL) and were derived from multiple stations selected from the marine boundary layer sites with well mixed background air (Ballantyne et al., 2012; Masarie and Tans, 1995). They applied conversion from concentrations to carbon mass is $1 \mathrm{ppm}=2.12 \mathrm{PgC}$ (Prather et al., 2012).

\subsection{Inversions}

For a comparison of yearly variability, spatial patterns, and latitudinal bands of NCE, we used annual means of 10 atmospheric $\mathrm{CO}_{2}$ inversions collected in Peylin et al. (2013), available at the same spatial and temporal resolution. Atmospheric $\mathrm{CO}_{2}$ inversions estimate the spatiotemporal explicit $\mathrm{CO}_{2}$ exchange between the Earth surface and atmosphere using atmospheric $\mathrm{CO}_{2}$ measurements and a transport model. Inversions have a closed budget by construction. The median and interquartile range for each year is taken over all 
Table 2. Net carbon exchange for different subsystems and variables that contribute to NCE (Eq. 1; negative numbers are surface uptake). Uncertainty (Unc.) is SD over ensemble runs. IAV is SD over annual values (2001-2010) and CV is coefficient of variation, computed as IAV divided by the mean.

\begin{tabular}{lrrrrrrrrrr}
\hline Variable & Marine & Rivers & Lakes & - NEP & Crops & Wood & $E_{\text {LUC }}$ & FF & Fire & NCE \\
\hline Mean & -1.60 & 0.65 & 0.32 & -18.41 & 2.68 & 0.71 & 0.83 & 7.78 & 1.81 & -5.45 \\
Unc. & 0.15 & 0.08 & & 2.08 & 0.21 & & 0.16 & & & 1.99 \\
IAV & 0.36 & & & 0.36 & 0.09 & & & 0.75 & 0.11 & \\
CV & 0.22 & & & 0.02 & 0.03 & & & 0.10 & 0.06 & 0.11 \\
\hline
\end{tabular}

available inversions for that year, as not all inversions were available until 2010. Atmospheric $\mathrm{CO}_{2}$ inversions estimate surface $\mathrm{CO}_{2}$ fluxes such that they best fit observed atmospheric constraints. They usually rely on prior information provided by terrestrial and oceanic biogeochemical models but are mostly independent from the bottom-up data sets included in the present synthesis. They further use FF as an input and then provide the surface-atmosphere flux excluding FF.

\section{Results}

\subsection{Global net carbon exchange}

Mean fluxes, their uncertainties, interannual variability (IAV), and CV (the mean-normalized IAV) for all individual fluxes contributing to NCE are presented in Table 2. Mean fluxes are also summarized graphically in Fig. 2 (mean over 2001-2010). Our best surface-data-driven bottom-up global estimate of NCE is $-5.4 \pm 2.0 \mathrm{PgC} \mathrm{yr}^{-1}$. That means that the observation-based data sets suggest a large net sink, even if FF and $E_{\mathrm{LUC}}$ are included in NCE. By contrast, the accurately measured $\mathrm{CO}_{2}$ growth rate constrains $\mathrm{NCE}$ to being a net $\mathrm{CO}_{2}$ source to the atmosphere of $4.3 \pm 0.1 \mathrm{PgC} \mathrm{yr}^{-1}$ (2001-2010, Le Quéré et al., 2015). Thus, there is a large mismatch with our NCE of $9.7 \pm 2.0 \mathrm{PgC} \mathrm{yr}^{-1}$. This highlights that our observation-based NCE is biased towards a too large sink. Potential reasons for this mismatch are discussed in Sect. 4. For most fluxes, uncertainty estimates strongly exceed IAV (Table 2). Interestingly, process-based models, which are only indirectly constrained by observations, provide an NCE that matches roughly the $\mathrm{CO}_{2}$ growth rate (Le Quéré et al., 2015). Developers of process-based models have access to $\mathrm{CO}_{2}$ growth rate data and may be in the position to tune their models so that they give realistic NCE values (Schwalm et al., 2015), whereas in our bottom-up approach, we conducted a blind up-scaling of ground measurements without trying to match the $\mathrm{CO}_{2}$ growth rate.
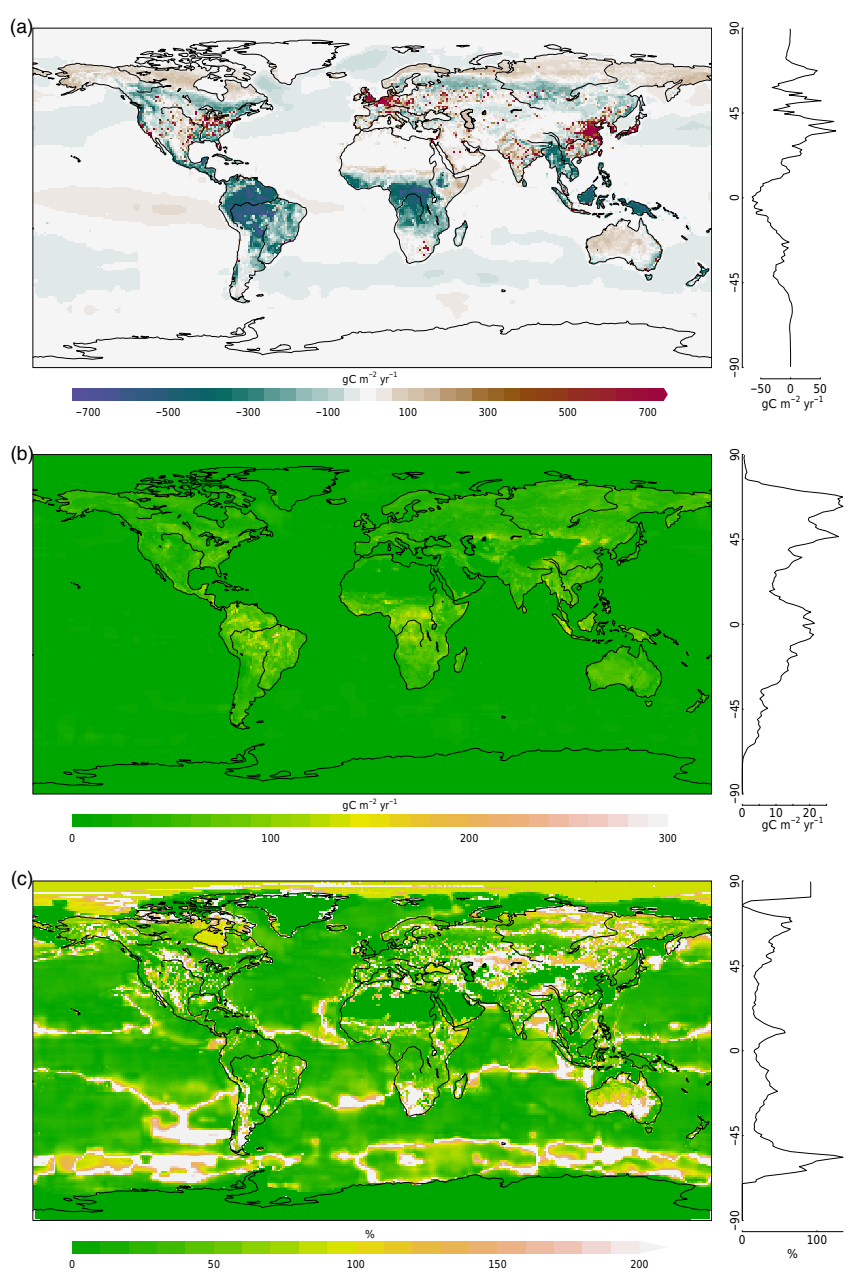

Figure 3. Gridded spatial patterns of NCE. (a) 2001-2010 decadal mean. (b) Uncertainty; 1SD across the NCE ensemble. (c) Relative uncertainty; uncertainty normalized by absolute mean. Latitudinal plots in (b) and (c) denote median across latitudes.

\subsection{Spatial patterns of net carbon exchange}

The 200-member NCE ensemble and the uncertainty distribution of each flux component enables us to provide a best estimate for a gridded average surface-atmosphere $\mathrm{CO}_{2}$ flux map for the time period 2001-2010 (Fig. 3a). According to these estimates, tropical land areas are a larger $\mathrm{CO}_{2}$ sink than 
the mid-latitudes despite the visible forest bands in North America and Russia that function as sinks. In contrast, the high latitudes indicate a relatively small source. In the ocean, these patterns are reversed, with sources in the tropics and a sink in the mid-latitudes. Clearly, there is a strong land-sea contrast and land NCE is much higher in magnitude compared to ocean NCE. In areas with high human population densities and active industry (Europe, eastern China, US, South Africa), emissions from fossil fuels and cement production clearly dominate the land $\mathrm{CO}_{2}$ fluxes.

Absolute uncertainty of NCE generally scales with the mean flux and is highest in the most productive areas over land (Amazon basin, Congo basin, Indonesia; Fig. 3b). Due to the small contribution of the oceans, absolute uncertainties are barely discernible there. Although gross air-sea exchange fluxes have typical uncertainties of more than $20 \%$, their differences are determined from independent measurements with a much higher accuracy (Ciais et al., 2013).

Relative uncertainties, however, show very distinct patterns (Fig. 3c). These are high on land in semi-arid and arid, and in mountainous regions (i.e. rather unproductive areas with near-zero mean) such as Australia, the Middle East, the Midwest US, the Sahel, South Africa, the Andes, and around the Tibetan Plateau. Marine-atmosphere $\mathrm{CO}_{2}$ exchange is most uncertain in relative terms in the Bay of Bengal and in the Southern Ocean, which is known to be undersampled, and where the two data-driven NCE fluxes show substantial regional patterns (Landschützer et al., 2014; Rödenbeck et al., 2014). In addition, linear features with high relative uncertainty are visible, especially in the Southern Hemisphere. These are related to the borders of the clusters used for deriving homogeneous regions of sea-air exchange in one of the ocean-exchange products, which result in this product in strong spatial gradients in the sea surface $p \mathrm{CO}_{2}$ (Landschützer et al., 2014). Relative uncertainties are mostly below $100 \%$ for the median across latitudinal bands (Fig. 3c). Only in the Southern Ocean is the relative uncertainty substantially higher, reflecting difficulties in reconstructing seasonal to interannual variabilities with sparse observational constraints (Landschützer et al., 2014; Rödenbeck et al., 2014). Nevertheless, Landschützer et al. (2015) have shown that there is a better agreement between the estimates of Landschützer et al. (2014) and Rödenbeck et al. (2014) when low-frequency variability, such as decadal variability, is analysed.

Averaged over latitudinal bands, the tropics are clearly a $\mathrm{CO}_{2}$ sink (Fig. 4a), a feature of the FLUXCOM models used for NEP, whereas mid-latitudes form a net $\mathrm{CO}_{2}$ source, mostly due to fossil fuel and cement emissions surpassing natural $\mathrm{CO}_{2}$ sinks. This latitudinal pattern is strongly driven by the terrestrial fluxes (Fig. 4b). Marine and land aquatic $\mathrm{CO}_{2}$ exchange in turn is about 4 times smaller in magnitude and shows $\mathrm{CO}_{2}$ sources in the tropics and $\mathrm{CO}_{2}$ sinks in the extratropics (Fig. 4c). The aquatic $\mathrm{CO}_{2}$ source in the tropics is not only the result of the ocean air-sea exchange, but also of the very intense river outgassing in low-latitude regions
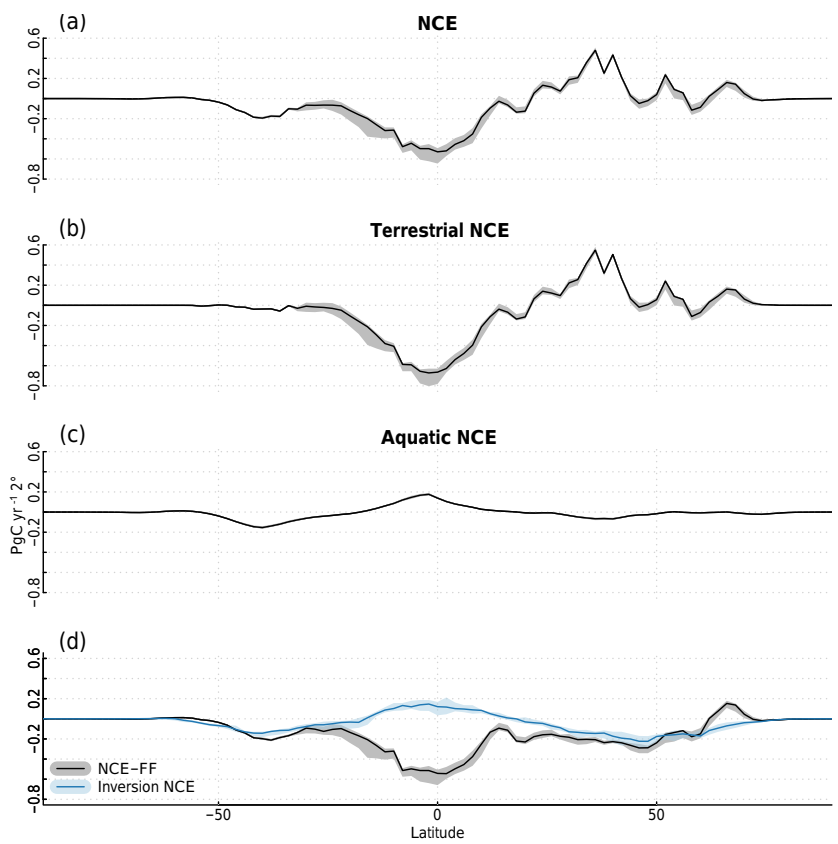

Figure 4. Median and interquartile range of different subsets of NCE (2001-2010 decadal mean). (a) All fluxes. (b) Terrestrial fluxes. (c) Aquatic fluxes. (d) NCE without fossil fuels from this synthesis (black) and from inversions (blue).

(Lauerwald et al., 2015). NCE in the mid-latitudes is dominated by fossil fuel emissions (black line in Fig. 4d shows NCE-FF). FF contribute little in the tropics and the high latitudes but offset land and ocean $\mathrm{CO}_{2}$ sinks in the northern mid-latitudes so that the net $\mathrm{CO}_{2}$ balance of this latitude band is a net $\mathrm{CO}_{2}$ source.

We use the land cover map of FLUXCOM to identify tropical forests (all pixels where broadleaved evergreen trees dominate). Tropical forest, which covers about $3.5 \%$ of the Earth's surface, are allocated a $\mathrm{CO}_{2}$ sink of $-5.0 \pm 0.6 \mathrm{PgC} \mathrm{yr}^{-1}$, which is unrealistic, if compared to, for example, forest biomass inventories (Pan et al., 2011). Without this large sink, global NCE would be of $-0.4 \pm 1.8 \mathrm{PgC} \mathrm{yr}^{-1}$. This corrected estimate (assuming neutral $\mathrm{C}$ exchange in tropical forests) is still a sink more than $4 \mathrm{PgC} \mathrm{yr}^{-1}$ larger than the global $\mathrm{NCE}$ accurately constrained by $\mathrm{CO}_{2}$ growth rate observations $\left(4.3 \pm 0.1 \mathrm{PgC} \mathrm{yr}^{-1}\right)$. Including missing fluxes (e.g. biogenic fluxes and emissions from wetlands; see Sect. 4.2) for which we do not have spatially explicit estimates (see Sect. 4.4) could close this gap. These considerations suggest that the $\mathrm{CO}_{2}$ sink of tropical forests from FLUXCOM is probably strongly overestimated and responsible for at least half of the global mismatch with the observed $\mathrm{CO}_{2}$ growth rate (see Sect. 4.1 for further discussion). 


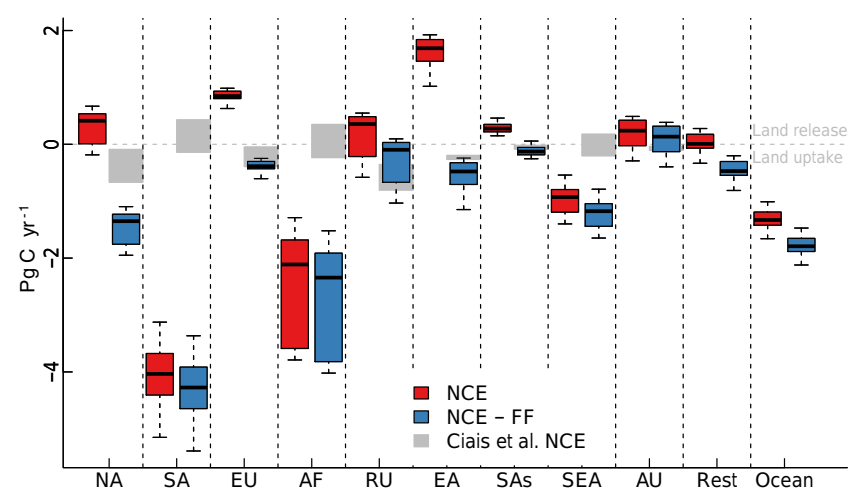

Figure 5. NCE (2001-2010 decadal mean) in RECCAP regions over land, including (red) and without fossil fuels (blue). Shown are median, interquartile range (box), and $1.5 \times$ interquartile range (whiskers). The regional estimates including uncertainties of NCE collected in Ciais et al. (2017) are underlain in grey. NA: North America; SA: South America; EU: Europe; AF: Africa; RU: Russia; EA: East Asia; SAs: South Asia; SEA: Southeast Asia; AU: Australia; Rest: remaining land areas.

\subsection{Net carbon exchange over the RECCAP regions}

\subsection{RECCAP over land}

Here we compare our NCE estimates over land with largely independent estimates of net ecosystem exchange (NEE) over continental-scale regions collected in RECCAP (REgional Carbon Cycle Assessment and Processes). Ciais et al. (2017) compiled regional estimates of land-atmosphere $\mathrm{CO}_{2}$ fluxes in the RECCAP regions from the original publications, complemented by river $\mathrm{CO}_{2}$ outgassing fluxes from Raymond et al. (2013) and Lauerwald et al. (2015). Thus, these estimates are not fully independent of those presented in this study because they use the same river fluxes, fire emissions, and FF emission. All other fluxes are independent. The RECCAP budgets were based on inventories, and in some instances on process models results. For $E_{\mathrm{LUC}}$, RECCAP publications used regional data sets or bookkeeping models (a bookkeeping model combines local or regional observationbased estimates of $\mathrm{C}$ stocks before land use change and trajectories of $\mathrm{C}$ stocks after land use change including slash, biomass, soil carbon, and harvested wood products with changing areas of different land use types, Houghton and Nassikas, 2017), that are independent from estimates gathered in Sect. 2.3.4. The RECCAP regions include North America (NA; King et al., 2015), South America (SA; Gloor et al., 2012), Europe (EU; Luyssaert et al., 2012), Africa (AF; Valentini et al., 2014), Russia (RU; Dolman et al., 2012), East Asia (EA; Piao et al., 2012), South Asia (SAs; Patra et al., 2013), and Australia (AU; Haverd et al., 2013). No regional study is yet available for Southeast Asia (SEA). Greenland, the Middle East, Ukraine, Kazakhstan and New Zealand are omitted in regional RECCAP studies because of the difficulty of obtaining local ground-based observations. Ciais et al. (2017) collected the regional estimates and combined them with estimates of lateral transport to estimate $\mathrm{C}$ budgets for each region. NEE in Ciais et al. (2017) minus $\mathrm{C}$ export by rivers should in principle be equal to our NCE estimates without FF over the same regions (Fig. 5). In regions without tropical forest except NA (that is, EU, RU, EA, SAs, and AU) the estimates by Ciais et al. (2017) are within the uncertainty range of our assessment. For NA and regions containing the tropics, our approach shows a much stronger C sink.

Using our methodology, the annual NCE-FF for all REC$\mathrm{CAP}$ regions amounts to $-11.0 \pm 1.9 \mathrm{PgC} \mathrm{yr}^{-1}$ in contrast to $-1.3 \pm 0.6 \mathrm{PgC} \mathrm{yr}^{-1}$ in Ciais et al. (2017). If we exclude SA, AF, and SEA, the numbers are $-2.8 \pm 1.0$ and $-1.5 \pm 0.4 \mathrm{PgC} \mathrm{yr}^{-1}$, respectively, bringing both estimates in each other's uncertainty range. For SA, AF and SEA, the two estimates even differ in sign. While our estimates indicate strong $\mathrm{C}$ sinks of $-4.3 \pm 0.5,-2.7 \pm 0.9$, and $-1.2 \pm 0.3 \mathrm{PgC} \mathrm{yr}^{-1}$, respectively, Ciais et al. (2017) report $0.1 \pm 0.3,0.1 \pm 0.3$, and $0.0 \pm 0.2 \mathrm{PgC} \mathrm{yr}^{-1}$.

Given that Ciais et al. (2017) rely on an independent method, this demonstrates that a relatively good understanding and observational coverage of net $\mathrm{C}$ fluxes exists for $\mathrm{EU}$, $\mathrm{RU}, \mathrm{AU}, \mathrm{SAs}$, and EA to some extent. It is somewhat surprising that both approaches largely differ over North America, where good observational coverage for instance through eddy covariance towers exist. The comparison also reveals the high uncertainties and biases in bottom-up estimates of NCE over tropical forests (see Sect. 3.2, but also Gloor et al., 2012; Valentini et al., 2014) and underlines the importance of long-term ground-based measurement campaigns in those regions (e.g. RAINFOR, http://www.rainfor.org/: Malhi et al., 2002; ATTO: Andreae et al., 2015; Zhou et al., 2014).

\subsubsection{RECCAP over ocean}

We compare our estimates of marine $\mathrm{C}$ exchange over the ocean with estimates from the RECCAP initiative. The Pacific Ocean is divided into North Pacific extratropics (NP), tropical pacific (TP), and South Pacific extratropics (SP) (Ishii et al., 2014). The Atlantic Ocean is divided into Arctic Ocean (AR), northern subtropics (NS), equatorial (EQ), and southern subtropics (SS) (Schuster et al., 2013). Further, there are estimates for the northern (NI) and southern Indian Ocean (SI) (Sarma et al., 2013) as well as for the Southern Ocean (SO) (Lenton et al., 2013). While there is large overlap between the $p \mathrm{CO}_{2}$ data used in the RECCAP estimates and our NCE estimates over oceans, different independent methods have been used to obtain flux estimates of ocean $\mathrm{CO}_{2}$ exchange (Sect. 2.2.1). Overall, the estimates from both sources agree very well (Fig. 6) and show ocean net $\mathrm{C}$ release in tropical regions (TP, EQ, and NI) and net $\mathrm{C}$ uptake in all other regions. In SO our estimates predict a smaller sink compared to the RECCAP estimates, a difference probably 


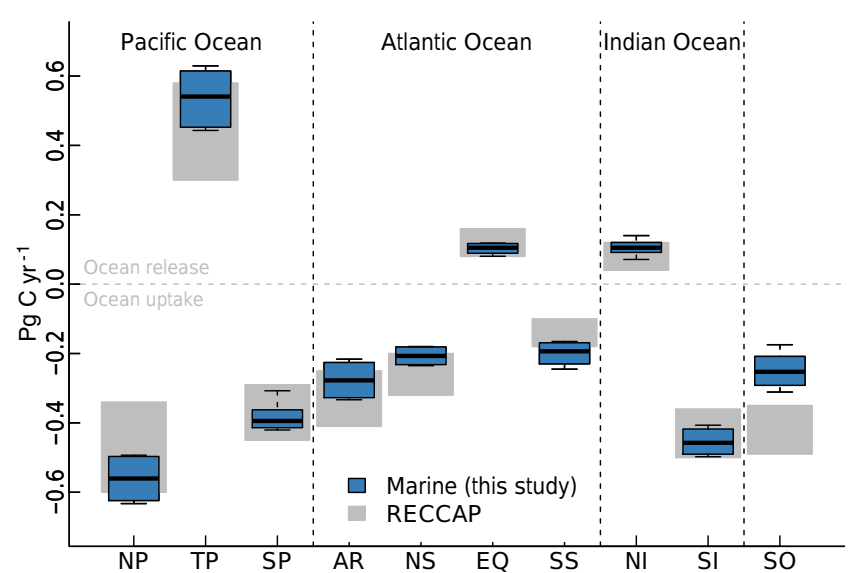

Figure 6. Marine NCE in RECCAP regions over the ocean. Shown are median, interquartile range (box), and $1.5 \times$ interquartile range (whiskers) of the Marine fluxes. The RECCAP estimates including uncertainties are underlain in grey. NP: North Pacific extratropics; TP: tropical pacific; SP: South Pacific extratropics; AR: Arctic Ocean; NS: northern subtropics; EQ: equatorial; SS: southern subtropics; NI: northern Indian Ocean; SI: southern Indian Ocean; SO: Southern Ocean.

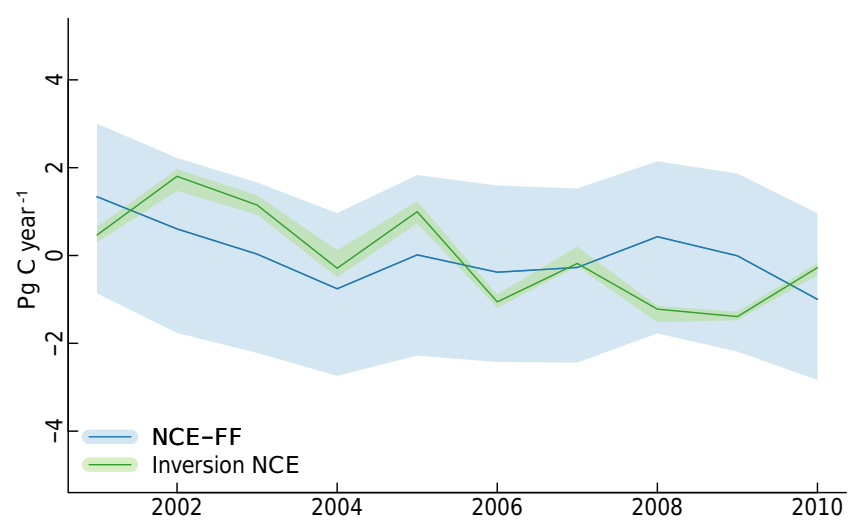

Figure 7. Comparison of NCE-FF with NCE from inversions (by construction without FF) on interannual timescales. Both time series were zero-centred by adding an offset of $13.23 \mathrm{PgC} \mathrm{yr}^{-1}$ for NCE-FF and 3.74 ${\mathrm{PgC} \mathrm{yr}^{-1}}^{-1}$ for NCE from inversions. Lines show median, shading denotes interquartile range.

owing to the weak observational constraint (Landschützer et al., 2014; Rödenbeck et al., 2014). Our estimates generally have smaller uncertainty ranges, which is because (i) the RECCAP studies include many more approaches (including process-based models, atmospheric and ocean inversions) in their estimates and (ii) in our analysis we include the uncertainty from the ocean $p \mathrm{CO} 2$ products and their realizations but do not account for the uncertainty in the kinetic gas transfer.

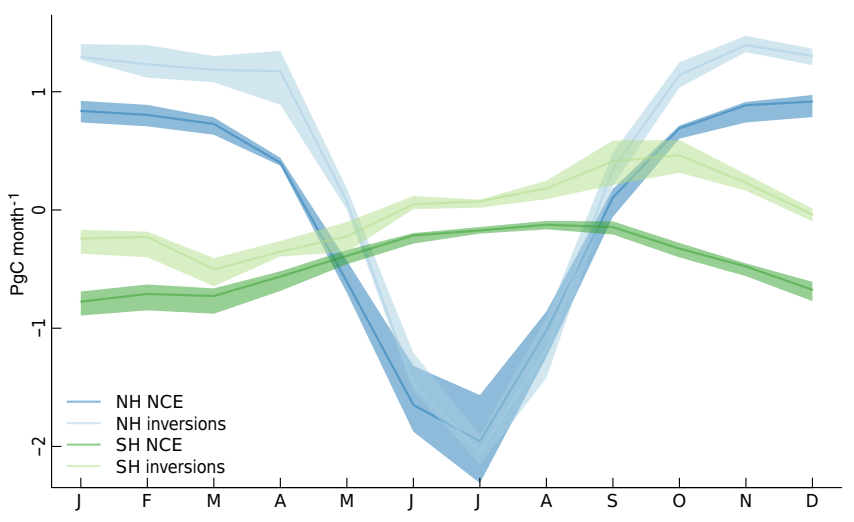

Figure 8. NCE median seasonal cycle and interquartile range for Northern Hemisphere ( $\mathrm{NH}, 0-90^{\circ} \mathrm{N}$, blue) and Southern Hemisphere ( $\mathrm{SH}, 90-0^{\circ} \mathrm{S}$, green) for estimates from this study (dark colours) and inversions (light colours).

\subsection{Comparison with inversions}

We compare NCE without FF (NCE-FF) with annual values from 10 inversions estimating the surface-atmosphere $\mathrm{CO}_{2}$ flux without FF (Peylin et al., 2013). While both estimates agree well in the mid-latitudes, they show opposite patterns in the tropics and northern high latitudes (Fig. 4d). The estimates of NEP in our NCE-FF probably have a substantial bias towards too much uptake over tropical land (Sect. 4.1). The comparison suggests that $\mathrm{CO}_{2}$ fluxes are comparably well constrained in the mid-latitudes where bottom-up and top-down approaches agree. Similar results have been obtained in a comparison of a bottom-up upscaling approach with a more recent inversion based on $\mathrm{CO}_{2}$ concentration data from the Greenhouse gases Observing SATellite (GOSAT; Kondo et al., 2015). The temporal evolution between both estimates show little agreement except the trend towards more net $\mathrm{C}$ uptake by the Earth's surface (Fig. 7). The comparison shows that NCE-FF estimated from this study has lower interannual variability compared to inversion estimates. Uncertainties are very high for our NCE-FF. In addition, the mean annual $\mathrm{C}$ uptake in our estimates is nearly $10 \mathrm{PgC} \mathrm{yr}^{-1}$ higher than for inversions.

\subsection{Monthly variability and mean seasonal cycle}

NCE in the Northern Hemisphere (NH) exhibits a much stronger mean seasonal cycle compared to the Southern Hemisphere ( $\mathrm{SH}$ ), ranging from a net $\mathrm{C}$ uptake of nearly $2 \mathrm{PgC}$ (per month) in July to a net $\mathrm{C}$ release of about $0.9 \mathrm{PgC}$ in December and January (Fig. 8). The SH is always a net $\mathrm{C}$ sink, ranging between slightly under $0.8 \mathrm{PgC}$ uptake in January to roughly $0.1 \mathrm{PgC}$ in August and September. This illustrates the "breathing of the Earth" - that is, vegetation activity largely follows the annual cycle of the sun. NH NCE is strongly offset by fossil fuel emissions. The uncertainties 
for the SH seasonal cycle are generally much lower than for the NH fluxes due to the larger contribution of the latter to the overall flux pattern, which is related to the distribution of land areas. If compared to inversions, we find that both estimates only match in the summer of the NH. In all other months and in the SH, our NCE estimates show a consistently much larger surface $\mathrm{C}$ sink. In addition, the NCE estimates from this synthesis show a smaller amplitude of the mean seasonal cycle compared to the inversions. The difference in amplitude of the mean seasonal cycle is on average $0.7 \mathrm{PgC}$ for the $\mathrm{NH}$ and $0.4 \mathrm{PgC}$ for the $\mathrm{SH}$.

\section{Current limitations of a bottom-up spatiotemporal assessment of net carbon exchange}

Our study shows that today's spatiotemporally explicit and independent bottom-up observation-driven estimates of surface-atmosphere $\mathrm{CO}_{2}$ exchange suffer from large bias, such that they do not match the global NCE well constrained from the $\mathrm{CO}_{2}$ growth rate. This statement is not downgrading the advances in the area, but rather a systematic reflection of the state of current research and monitoring. In fact, at the regional scale, those estimates are often well constrained and may be used for model-data integration studies and validation purposes. The regions where observationdriven $\mathrm{CO}_{2}$ exchange is constrained the best include Europe, Russia, South Asia, East Asia, Australia and all oceanic regions except the Southern Ocean. The most likely candidate for inducing the mismatch between data-driven estimates and the atmospheric $\mathrm{CO}_{2}$ growth rate is terrestrial NEP. In particular, tropical NEP estimates suggest a too large tropical sink. In the following sections, we discuss (i) the possible reasons for the large bias in NEP (Sect. 4.1), (ii) which fluxes are missing in our synthesis (Sect. 4.2), (iii) how this synthesis data set could be used for model-data fusion (Sect. 4.3), (iv) uncertainties in fire emissions (Sect. 4.4), and (v) the impact of missing seasonal cycles in some of the data sets (Sect. 4.5).

\subsection{Difficulties in estimating NEP over land}

Correctly predicting NEP from remote sensing requires establishing universal relationships between those predictors and respiratory processes (Jägermeyr et al., 2014; Tramontana et al., 2016). However, predicting such processes still poses major challenges to researchers (Trumbore, 2006). The $\mathrm{CO}_{2}$ flux related to heterotrophic decomposition processes, for instance, relates to factors controlling biological activity via temperature, moisture availability, and the decomposable substrate material. The question how soil respiration or total ecosystem respiration depends on these variables is not yet entirely understood. Advancing our knowledge on these processes is challenging due to both a lack of theory of res- piration and the difficulty of obtaining relevant data to test models (Trumbore, 2006).

In addition to a good theory for respiration, information on disturbance history (e.g. time since last fire) and forest age would improve the upscaling of NEP from sites to regions (Ciais et al., 2014). Disturbances that cause physical damage to vegetation properties tend to temporarily increase respiration and reduce photosynthesis and thus alter the balance between gross $\mathrm{C}$ uptake and release. Disturbed ecosystems are thus initially assumed to be strong $\mathrm{C}$ sources until plant production recovers. However, how these regrowth processes compensate a given disturbance regime cannot yet be quantified at global scales, as the area covered by disturbed ecosystems is variable and unknown (Ciais et al., 2014). For example, regrowth of vegetation after fires and other disturbances is not well sampled neither in the FLUXNET stations nor in the set of predictors used by the FLUXCOM models and is assumed to be implicit in our NEP estimate. Furthermore, management can have strong effects on annual NEP of croplands, which form large parts of the land surface (Jung et al., 2011). However, not all of the relevant predictors (i.e. disturbance maps, management practices, soil moisture) are currently available to be included in empirical upscaling exercises (Tramontana et al., 2016).

In addition to the above difficulties, some regions are undersampled by eddy covariance towers and thus NEP is not well constrained. This is the case for tropical forests and the northern high latitudes. In the tropics, undersampling leads to a large overestimation of net $\mathrm{CO}_{2}$ uptake in comparison to inversion and forest inventories (Peylin et al., 2013; Pan et al., 2011), whereas in the high latitudes it leads to a comparably large $\mathrm{CO}_{2}$ release (Fig. 4).

Given the difference between NCE and inversions in the tropics (Fig. 4), we can assume that a bias of FLUXCOM NEP towards a too high $\mathrm{C}$ sink is the main reason why the $\mathrm{C}$ budget is not closed in our approach. This raises the question why upscaled NEP has such a strong systematic bias towards a sink, particularly in the tropics (see also Jung et al., 2011). We suspect that the eddy covariance towers collected in FLUXNET, which provide the empirical basis for the global data-driven estimates (see Sect. 2.3.1) do not represent the different age classes of forests very well. For instance, young and regrowing forests with a generally higher-thanaverage NEP are possibly over-represented in FLUXNET. However, such an age dependency (Amiro et al., 2010; Coursolle et al., 2012; Hyvönen et al., 2007; Magnani et al., 2007) has not yet been included in global upscaling of NEP. This hypothesis should be tested in future upscaling exercises.

\subsection{Missing fluxes}

Due to a focus on spatially explicit maps, not all known fluxes between the land surface and the atmosphere are considered in our analysis. We assume that including the following fluxes may have an influence on the regional and global 
flux estimates (estimates of the flux magnitude are given if known):

- emissions from biogenic volatile organic compounds (VOCs) amount to approximately $0.76 \mathrm{PgC} \mathrm{yr}^{-1}$ globally (Sindelarova et al., 2014);

- $\mathrm{CO}_{2}$ emissions from wetlands, estimated globally at around 2.1 $\mathrm{PgC}^{-1}{ }^{-1}$ (Aufdenkampe et al., 2011);

- $\mathrm{CH}_{4}$ emissions from biogenic sources and animals;

- crop residues burning in households;

- biofuel burning;

- changes in land management, e.g. shifts in agriculture, soil tillage, grassland ploughing and grazing;

- geological fluxes;

- Raymond et al. (2013) estimate a much higher river evasion $\left(1.8 \mathrm{PgC} \mathrm{yr}^{-1}\right.$ instead of $0.65 \mathrm{PgC} \mathrm{yr}^{-1}$ used in this study).

All known missing fluxes add up to an additional $\mathrm{C}$ release of about $4 \mathrm{PgC} \mathrm{yr}^{-1}$. Although substantial, they do not cover the mismatch of more than $9 \mathrm{PgC} \mathrm{yr}^{-1}$ by far (Sect. 3.1). However, they would suffice to close the budget if tropical forests are assumed to be $\mathrm{C}$ neutral (tropical forests are responsible for a net $\mathrm{C}$ sink of about $5 \mathrm{PgC} \mathrm{yr}^{-1}$, Sect. 3.2). This significant amount of missing fluxes prohibits constraining FLUX$\mathrm{COM}$ runs with all the remaining fluxes. In other words, we cannot be certain of the bias in upscaled NEP as long as the major fluxes are not quantified in a spatially explicit manner. Emissions from VOCs and wetlands should thus receive particular attention if a consistent spatiotemporal picture of vertical $\mathrm{CO}_{2}$ exchange is to be obtained.

\subsection{Uncertainty estimates and model-data fusion}

Our uncertainty estimates of ocean and land $\mathrm{C}$ exchange likely underestimate the true uncertainty. In particular, Landschützer et al. (2014) estimated that the choice of sea-air gas transfer formulation (also including other relationships than quadratic) and the $p \mathrm{CO}_{2}$ mapping mismatch lead to an uncertainty of $37 \%$ for the global average over sea-air exchange between 1998 and 2011, with the majority of this uncertainty stemming from the gas transfer formulation. Furthermore, the uncertainty of NEP is likely underestimated because all upscaling methods in FLUXCOM use the same set of predictors (Tramontana et al., 2016). Hence, the uncertainty estimates only cover the uncertainty related to the upscaling method but do not contain uncertainties related to the selection of predictors or observational uncertainty of the predictors themselves.

A comprehensive spatiotemporally explicit bottom-up estimate of NCE can be a powerful ingredient for model-data integration exercises (Rayner et al., 2005). Yet model-data integration requires uncertainty characteristics of all data streams used (Raupach et al., 2005). Furthermore, it is important that uncertainties can be described in terms of random errors (Ciais et al., 2014). Error estimates at the local or regional level are difficult to use if no spatial error covariance matrix is available. The uncertainty analysis presented in this study obtained through Monte Carlo sampling aims to be of use for model-data integration studies. Errors are automatically propagated through different spatial resolutions by aggregating the individual ensembles of NCE. Naturally, efforts should be made to obtain error estimates for all integrated data sets (i.e. Wood, Fires, Shelves, Estuaries, and Lakes). Nevertheless, this first integrated NCE estimate offers new possibilities for approaches such as the Carbon Cycle Data Assimilation System (CCDAS; Rayner et al., 2005), by providing not only a full spatiotemporal grid of fluxes but also a transparent and consistent error propagation scheme. This can have also practical applications, for instance for designing new measurement campaigns in regions with high uncertainties to reduce knowledge gaps in the global $\mathrm{CO}_{2}$ fluxes.

\subsection{Uncertainties in fire emissions}

Fire emission estimates combine satellite-based fire data with ecosystems models. Uncertainties in global fire emission estimates are substantial and different fire products vary largely by location, vegetation type, and fire weather (Ciais et al., 2014; French et al., 2011).

While GFED4 burned-area estimates come with regional uncertainty estimates (Giglio et al., 2013), the actual uncertainty of $\mathrm{C}$ emissions from fires are probably much larger, of the order of $50 \%$ (van der Werf et al., 2017). The uncertainties of fire emission estimates depend regionally and temporally on the various input data sets such as burned area, small fire burned area, biomass loadings, and combustion completeness. Better quantifying this uncertainty requires an assessment of the burned-area estimates as well as new field data on fuel consumption and emission factors. In this study we cannot propagate this uncertainty into the NCE estimates as this would require spatiotemporal error covariance matrices.

\subsection{Seasonality for coastal and inland waters, wood and crop harvest emissions}

Recently, major steps have been undertaken to resolve the spatial variability of coastal and inland water $\mathrm{CO}_{2}$ fluxes (Laruelle et al., 2013, 2014; Lauerwald et al., 2015; Raymond et al., 2013). Estimates of the seasonal variation in these fluxes are necessary to better constrain seasonal variations in NCE. For inland waters, seasonality has so far only been investigated at regional scale (Laruelle et al., 2015; Richey et al., 2002). For shelves some seasonal estimates 
are currently available in temperate and high latitudes, indicating that net $\mathrm{C}$ uptake is highest in spring, whereas $\mathrm{C}$ release is highest in summer (Laruelle et al., 2014, 2017). These estimates indicate that seasonal differences in shelf net $\mathrm{C}$ exchange are as high as the annually integrated latitudinal gradient. An analysis performed over Atlantic shelves suggests that the seasonal variability in the air-sea $\mathrm{CO}_{2}$ exchange is most pronounced over temperate latitudes. In these regions, shelves generally behave as strong $\mathrm{CO}_{2}$ sinks in winter and spring, partly sustained by $\mathrm{CO}_{2}$ fixation during the spring phytoplankton bloom, but can become mild $\mathrm{CO}_{2}$ sources to the atmosphere in summer due to the effect of temperature-driven decrease $\mathrm{CO}_{2}$ solubility in water (Laruelle et al., 2014). Such behaviour is consistent with that of the open ocean at similar latitudes (Takahashi et al., 2009). In the continental shelves surrounding other oceanic basins, however, a recent study suggests more complex seasonal patterns involving the contributions of processes other than temperature to the seasonality of coastal $p \mathrm{CO}_{2}$ (Laruelle et al., 2017).

Biogenic $\mathrm{C}$ emissions related to tropical aboveground biomass loss as well as crop and wood harvest were equally distributed across months in this study. When exactly $\mathrm{C}$ emissions from humans and livestock occur is difficult to predict and would require more detailed consumption data (Wolf et al., 2015a).

\section{Conclusions}

From the presented synthesis, we draw the following main conclusions:

i. Current estimates of surface-atmosphere $\mathrm{CO}_{2}$ exchanges that are spatiotemporally explicit and entirely driven by surface observation are not sufficiently well constrained to close the $\mathrm{C}$ budget at the global scale. The data-driven estimates show a large bias towards too much $\mathrm{C}$ uptake by the Earth surface of nearly $10 \mathrm{PgC} \mathrm{yr}^{-1}$.

ii. The most likely candidate for inducing the mismatch between data-driven surface-atmosphere $\mathrm{CO}_{2}$ exchange and the atmospheric $\mathrm{CO}_{2}$ growth rate is land NEP. In particular, tropical NEP estimates appear to be strongly overestimated (too large land sink). Understanding this bias will help designing better upscaling approaches (e.g. by including currently missing relevant predictors) and pinpointing variables that need to be (better) monitored in the future.

iii. Regionally, the estimates of NCE are partly well constrained and may be used for model-data integration studies, validation of models, and evaluating claims and potentials of net $\mathrm{C}$ uptake within the framework of the Paris Agreement (UNFCCC, 2015). These regions include Europe, Russia, South Asia, East Asia, Australia, and most oceanic regions. Better constraining $\mathrm{C}$ fluxes in regions with currently high uncertainties should be a priority of future research.

Data availability. All variables used in Eq. (1) (including all ensembles runs listed in Table 1) are available for download (20012010, monthly, $1^{\circ}$ ). For NCE we provide the 200 ensemble runs which are used in this study. The landing page of the DOI is a data portal. After registration any user can download the data without restriction (https://dx.doi.org/10.17871/GEOCARBON_synth_ obs_v2).

\section{The Supplement related to this article is available online at https://doi.org/10.5194/bg-14-3685-2017-supplement.}

Competing interests. The authors declare that they have no conflict of interest.

Acknowledgements. This study was funded by the European Union in the context of the FP7 project GEOCARBON (grant agreement \#283080). Authors affiliated with [2] and [16] further acknowledge the EU for support via the H2020 project BACI (grant agreement \#640176). Authors affiliated with [5] thank the SAMPLES project as part of the CGIAR research program CCAFS, and CIFOR from the governments of Australia (grant agreement \#46167) and Norway (grant agreement \#QZA-10/0468). Nuno Carvalhais acknowledges funding from the NOVA grant UID/AMB/04085/2013. Goulven G. Laruelle is "Chargé de recherches F.R.S.-FNRS" at ULB. Ronny Lauerwald received funding from ANR (ANR-10-LABX-0018) and BRIC at ULB. Jens Hartmann and Ronny Lauerwald received funding from the German Science Foundation (DFG) (HA4472/6-1 and the cluster of excellence CLISAP, DFG EXEC 177, Hamburg). Leonardo Calle acknowledges funding from a NASA Earth and Space Science Fellowship. We also acknowledge the European Commission, Joint Research Centre (JRC)/Netherlands Environmental Assessment Agency (PBL) for providing the Emission Database for Global Atmospheric Research (EDGAR), release version EDGARv4.2.

The article processing charges for this open-access publication were covered by the Max Planck Society.

Edited by: Trevor Keenan

Reviewed by: two anonymous referees

\section{References}

Amiro, B. D., Barr, A. G., Barr, J. G., Black, T. A., Bracho, R., Brown, M., Chen, J., Clark, K. L., Davis, K. J., Desai, A. R., Dore, S., Engel, V., Fuentes, J. D., Goldstein, A. H., Goulden, M. L., Kolb, T. E., Lavigne, M. B., Law, B. E., Margolis, H. 
A., Martin, T., McCaughey, J. H., Misson, L., Montes-Helu, M., Noormets, A., Randerson, J. T., Starr, G., and Xiao, J.: Ecosystem carbon dioxide fluxes after disturbance in forests of North America, J. Geophys. Res.-Biogeo., 115, G00K02, https://doi.org/10.1029/2010JG001390, 2010.

Andreae, M. O., Acevedo, O. C., Araùjo, A., Artaxo, P., Barbosa, C. G. G., Barbosa, H. M. J., Brito, J., Carbone, S., Chi, X., Cintra, B. B. L., da Silva, N. F., Dias, N. L., Dias-Júnior, C. Q., Ditas, F., Ditz, R., Godoi, A. F. L., Godoi, R. H. M., Heimann, M., Hoffmann, T., Kesselmeier, J., Könemann, T., Krüger, M. L., Lavric, J. V., Manzi, A. O., Lopes, A. P., Martins, D. L., Mikhailov, E. F., Moran-Zuloaga, D., Nelson, B. W., Nölscher, A. C., Santos Nogueira, D., Piedade, M. T. F., Pöhlker, C., Pöschl, U., Quesada, C. A., Rizzo, L. V., Ro, C. U., Ruckteschler, N., Sá, L. D. A., de Oliveira Sá, M., Sales, C. B., dos Santos, R. M. N., Saturno, J., Schöngart, J., Sörgel, M., de Souza, C. M., de Souza, R. A. F., Su, H., Targhetta, N., Tóta, J., Trebs, I., Trumbore, S., van Eijck, A., Walter, D., Wang, Z., Weber, B., Williams, J., Winderlich, J., Wittmann, F., Wolff, S., and Yáñez-Serrano, A. M.: The Amazon Tall Tower Observatory (ATTO): overview of pilot measurements on ecosystem ecology, meteorology, trace gases, and aerosols, Atmos. Chem. Phys., 15, 10723-10776, https://doi.org/10.5194/acp-15-10723-2015, $2015 .$.

Atlas, R., Hoffman, R. N., Ardizzone, J., Leidner, S. M., Jusem, J. C., Smith, D. K., and Gombos, D.: A Cross-Calibrated Multiplatform Ocean Surface Wind Velocity Product for Meteorological and Oceanographic Applications, B. Am. Meteorol. Soc., 92, 157-174, 2011.

Aufdenkampe, A. K., Mayorga, E., Raymond, P. A., Melack, J. M., Doney, S. C., Alin, S. R., Aalto, R. E., and Yoo, K.: Riverine coupling of biogeochemical cycles between land, oceans and atmosphere, Front. Ecol. Environ., 9, 53-60, 2011.

Bakker, D. C. E., Pfeil, B., Smith, K., Hankin, S., Olsen, A., Alin, S. R., Cosca, C., Harasawa, S., Kozyr, A., Nojiri, Y., O’Brien, K. M., Schuster, U., Telszewski, M., Tilbrook, B., Wada, C., Akl, J., Barbero, L., Bates, N. R., Boutin, J., Bozec, Y., Cai, W. J., Castle, R. D., Chavez, F. P., Chen, L., Chierici, M., Currie, K., de Baar, H. J. W., Evans, W., Feely, R. A., Fransson, A., Gao, Z., Hales, B., Hardman-Mountford, N. J., Hoppema, M., Huang, W. J., Hunt, C. W., Huss, B., Ichikawa, T., Johannessen, T., Jones, E. M., Jones, S. D., Jutterström, S., Kitidis, V., Körtzinger, A., Landschützer, P., Lauvset, S. K., Lefèvre, N., Manke, A. B., Mathis, J. T., Merlivat, L., Metzl, N., Murata, A., Newberger, T., Omar, A. M., Ono, T., Park, G. H., Paterson, K., Pierrot, D., Ríos, A. F., Sabine, C. L., Saito, S., Salisbury, J., Sarma, V. V. S. S., Schlitzer, R., Sieger, R., Skjelvan, I., Steinhoff, T., Sullivan, K. F., Sun, H., Sutton, A. J., Suzuki, T., Sweeney, C., Takahashi, T., Tjiputra, J., Tsurushima, N., van Heuven, S. M. A. C., Vandemark, D., Vlahos, P., Wallace, D. W. R., Wanninkhof, R., and Watson, A. J.: An update to the Surface Ocean $\mathrm{CO}_{2}$ Atlas (SOCAT version 2), Earth Syst. Sci. Data, 6, 69-90, https://doi.org/10.5194/essd-6-69-2014, 2014.

Baldocchi, D.: Measuring fluxes of trace gases and energy between ecosystems and the atmosphere - the state and future of the eddy covariance method, Glob. Change Biol., 20, 3600-3609, 2014.

Ballantyne, A. P., Alden, C. B., Miller, J. B., Tans, P. P., and White, J. W. C.: Increase in observed net carbon dioxide uptake by land and oceans during the past 50 years, Nature, 488, 70-72, 2012.
Berger, M., Moreno, J., Johannessen, J. A., Levelt, P. F., and Hanssen, R. F.: ESA's sentinel missions in support of Earth system science, Remote Sens. Environ., 120, 84-90, 2012.

Canadell, J. G., Ciais, P., Gurney, K., Le Quéré, C., Piao, S., Raupach, M. R., and Sabine, C. L.: An International Effort to Quantify Regional Carbon Fluxes, EOS, 92, 81-82, 2011.

Ciais, P., Dolman, A., Bombelli, A., Duren, R., Peregon, A., Rayner, P., Miller, C., Gobron, N., Kinderman, G., and Marland, G.: Current systematic carbon-cycle observations and the need for implementing a policy-relevant carbon observing system, Biogeosciences, 11, 3547-3602, https://doi.org/10.5194/bg11-3547-2014, 2014.

Ciais, P., Gasser, T., Lauerwald, R., Peng, S., Raymond, P. A., Wang, Y., Canadell, J. G., Peters, G. P., Andres, R. J., Chang, J., Yue, C., Dolman, A. J., Haverd, V., Hartmann, J., Laruelle, G., King, A. W., Liu, Y., Luyssaert, S., Maignan, F., Patra, P. K., Peregon, A., Regnier, P., Piao, S., Poulter, B., Shvidenko, A., Valentini, R., Wang, R., van Dijk, A. I. J. M., Broquet, G., Yin, Y., Zscheischler, J., and Zhu, D.: Observed regional carbon budgets imply reduced soil heterotrophic respiration, Nature, in review, 2017.

Ciais, P., Sabine, C., Bala, G., Bopp, L., Brovkin, V., Canadell, J., Chhabra, A., DeFries, R., Galloway, J., Heimann, M., Jones, C., Le Queìreì, C., Myneni, R. B., Piao, S., and Thornton, P.: Carbon and Other Biogeochemical Cycles, in: Climate Change 2013: The Physical Science Basis, Contribution of Working Group I to the Fifth Assessment Report of the Intergovernmental Panel on Climate Change, edited by: Stocker, T. F., Qin, D., Plattner, G.K., Tignor, M., Allen, S. K., Boschung, J., Nauels, A., Xia, Y., Bex, V., and Midgley, P. M., Cambridge University Press, Cambridge, United Kingdom and New York, NY, USA, 2013.

Coursolle, C., Margolis, H. A., Giasson, M. A., Bernier, P. Y., Amiro, B. D., Arain, M. A., Barr, A. G., Black, T. A., Goulden, M. L., McCaughey, J. H., Chen, J. M., Dunn, A. L., Grant, R. F., and Lafleur, P. M.: Influence of stand age on the magnitude and seasonality of carbon fluxes in Canadian forests, Agr. Forest Meteorol., 165, 136-148, 2012.

Dee, D. P., Uppala, S. M., Simmons, A. J., Berrisford, P., Poli, P., Kobayashi, S., Andrae, U., Balmaseda, M. A., Balsamo, G., Bauer, P., Bechtold, P., Beljaars, A. C. M., van de Berg, L., Bidlot, J., Bormann, N., Delsol, C., Dragani, R., Fuentes, M., Geer, A. J., Haimberger, L., Healy, S. B., Hersbach, H., Holm, E. V., Isaksen, L., Kallberg, P., Kohler, M., Matricardi, M., McNally, A. P., Monge-Sanz, B. M., Morcrette, J. J., Park, B. K., Peubey, C., de Rosnay, P., Tavolato, C., Thepaut, J. N., and Vitart, F.: The ERA-Interim reanalysis: configuration and performance of the data assimilation system, Q. J. Roy. Meteor. Soc., 137, 553-597, 2011.

Dolman, A. J., Shvidenko, A., Schepaschenko, D., Ciais, P., Tchebakova, N., Chen, T., van der Molen, M. K., Belelli Marchesini, L., Maximov, T. C., Maksyutov, S., and Schulze, E. D.: An estimate of the terrestrial carbon budget of Russia using inventory-based, eddy covariance and inversion methods, Biogeosciences, 9, 5323-5340, https://doi.org/10.5194/bg-9-53232012, 2012.

Dürr, H. H., Laruelle, G. G., van Kempen, C. M., Slomp, C. P., Meybeck, M., and Middelkoop, H.: Worldwide Typology of Nearshore Coastal Systems: Defining the Estuarine Filter of River Inputs to the Oceans, Estuar. Coast., 34, 441-458, 2011. 
Earles, J. M., Yeh, S., and Skog, K. E.: Timing of carbon emissions from global forest clearance, Nature Climate Change, 2, 682$685,2012$.

Fekete, B. M., Vorosmarty, C. J., and Grabs, W.: High-resolution fields of global runoff combining observed river discharge and simulated water balances, Global Biogeochem. Cy., 16, https://doi.org/10.1029/1999GB001254, 2002.

French, N. H. F., de Groot, W. J., Jenkins, L. K., Rogers, B. M., Alvarado, E., Amiro, B., de Jong, B., Goetz, S., Hoy, E., Hyer, E., Keane, R., Law, B. E., McKenzie, D., McNulty, S. G., Ottmar, R., Perez-Salicrup, D. R., Randerson, J., Robertson, K. M., and Turetsky, M.: Model comparisons for estimating carbon emissions from North American wildland fire, J. Geophys. Res.Biogeo., 116, G00K05, https://doi.org/10.1029/2010JG001469, 2011.

Giglio, L., Randerson, J. T., and van der Werf, G. R.: Analysis of daily, monthly, and annual burned area using the fourthgeneration global fire emissions database (GFED4), J. Geophys. Res.-Biogeo., 118, 317-328, 2013.

GLOBALVIEW-CO2: Cooperative atmospheric data integration project-Carbon dioxide. Multi-laboratory compilation of synchronized and gap-filled atmospheric carbon dioxide records for the period 1979-2011, NOAA ESRL, Boulder, 2012.

Gloor, M., Gatti, L., Brienen, R., Feldpausch, T. R., Phillips, O. L., Miller, J., Ometto, J. P., Rocha, H., Baker, T., de Jong, B., Houghton, R. A., Malhi, Y., Aragão, L. E. O. C., Guyot, J. L., Zhao, K., Jackson, R., Peylin, P., Sitch, S., Poulter, B., Lomas, M., Zaehle, S., Huntingford, C., Levy, P., and Lloyd, J.: The carbon balance of South America: a review of the status, decadal trends and main determinants, Biogeosciences, 9, 5407-5430, https://doi.org/10.5194/bg-9-5407-2012, 2012.

Harris, N. L., Brown, S., Hagen, S. C., Saatchi, S. S., Petrova, S., Salas, W., Hansen, M. C., Potapov, P. V., and Lotsch, A.: Baseline Map of Carbon Emissions from Deforestation in Tropical Regions, Science, 336, 1573-1576, 2012.

Hartmann, J., Lauerwald, R., and Moosdorf, N.: A brief overview of the GLObal RIver CHemistry Database, GLORICH, Procedia Earth and Planetary Science, 10, 23-27, 2014.

Haverd, V., Raupach, M. R., Briggs, P. R., Canadell, J. G., Davis, S. J., Law, R. M., Meyer, C. P., Peters, G. P., Pickett-Heaps, C., and Sherman, B.: The Australian terrestrial carbon budget, Biogeosciences, 10, 851-869, https://doi.org/10.5194/bg-10-851-2013, 2013.

Hayes, D. J., Turner, D. P., Stinson, G., McGuire, A. D., Wei, Y., West, T. O., Heath, L. S., de Jong, B., McConkey, B. G., Birdsey, R. A., Kurz, W. A., Jacobson, A. R., Huntzinger, D. N., Pan, Y., Post, W. M., and Cook, R. B.: Reconciling estimates of the contemporary North American carbon balance among terrestrial biosphere models, atmospheric inversions, and a new approach for estimating net ecosystem exchange from inventory-based data, Glob. Change Biol., 18, 1282-1299, 2012.

Houghton, R. A.: Balancing the global carbon budget, Annu. Rev. Earth Pl. Sc., 35, 313-347, 2007.

Houghton, R. A. and Nassikas, A. A.: Global and regional fluxes of carbon from land use and land cover change 1850-2015, Global Biogeochem. Cy., 31, 456-472, 2017.

Hyvönen, R., Agren, G. I., Linder, S., Persson, T., Cotrufo, M. F., Ekblad, A., Freeman, M., Grelle, A., Janssens, I. A., Jarvis, P. G., Kellomaki, S., Lindroth, A., Loustau, D., Lundmark, T., Norby,
R. J., Oren, R., Pilegaard, K., Ryan, M. G., Sigurdsson, B. D., Stromgren, M., van Oijen, M., and Wallin, G.: The likely impact of elevated $\left[\mathrm{CO}_{2}\right]$, nitrogen deposition, increased temperature and management on carbon sequestration in temperate and boreal forest ecosystems: a literature review, New Phytol., 173, 463-480, 2007.

Ishii, M., Feely, R. A., Rodgers, K. B., Park, G.-H., Wanninkhof, R., Sasano, D., Sugimoto, H., Cosca, C. E., Nakaoka, S., Telszewski, M., Nojiri, Y., Mikaloff Fletcher, S. E., Niwa, Y., Patra, P. K., Valsala, V., Nakano, H., Lima, I., Doney, S. C., Buitenhuis, E. T., Aumont, O., Dunne, J. P., Lenton, A., and Takahashi, T.: Air-sea $\mathrm{CO}_{2}$ flux in the Pacific Ocean for the period 1990-2009, Biogeosciences, 11, 709-734, https://doi.org/10.5194/bg-11-709-2014, 2014.

Jägermeyr, J., Gerten, D., Lucht, W., Hostert, P., Migliavacca, M., and Nemani, R.: A high-resolution approach to estimating ecosystem respiration at continental scales using operational satellite data, Glob. Change Biol., 20, 1191-1210, 2014.

Jähne, B., Munnich, K. O., Bosinger, R., Dutzi, A., Huber, W., and Libner, P.: On the Parameters Influencing Air-Water GasExchange, J. Geophys. Res.-Ocean., 92, 1937-1949, 1987.

Jung, M., Reichstein, M., Margolis, H. A., Cescatti, A., Richardson, A. D., Arain, M. A., Arneth, A., Bernhofer, C., Bonal, D., Chen, J. Q., Gianelle, D., Gobron, N., Kiely, G., Kutsch, W., Lasslop, G., Law, B. E., Lindroth, A., Merbold, L., Montagnani, L., Moors, E. J., Papale, D., Sottocornola, M., Vaccari, F., and Williams, C.: Global patterns of landatmosphere fluxes of carbon dioxide, latent heat, and sensible heat derived from eddy covariance, satellite, and meteorological observations, J. Geophys. Res.-Biogeo., 116, G00J07, https://doi.org/10.1029/2010JG001566, 2011.

King, A. W., Andres, R. J., Davis, K. J., Hafer, M., Hayes, D. J., Huntzinger, D. N., de Jong, B., Kurz, W. A., McGuire, A. D., Vargas, R., Wei, Y., West, T. O., and Woodall, C. W.: North America's net terrestrial $\mathrm{CO}_{2}$ exchange with the atmosphere 1990 2009, Biogeosciences, 12, 399-414, https://doi.org/10.5194/bg12-399-2015, 2015..

Kondo, M., Ichii, K., Takagi, H., and Sasakawa, M.: Comparison of the data-driven top-down and bottom-up global terrestrial $\mathrm{CO}_{2}$ exchanges: GOSAT $\mathrm{CO}_{2}$ inversion and empirical eddy flux upscaling, J. Geophys. Res.-Biogeo., 120, 1226-1245, 2015.

Landschützer, P., Gruber, N., Bakker, D. C. E., and Schuster, U.: Recent variability of the global ocean carbon sink, Global Biogeochem. Cy., 28, 927-949, 2014.

Landschützer, P., Gruber, N., Haumann, F. A., Rödenbeck, C., Bakker, D. C. E., van Heuven, S., Hoppema, M., Metzl, N., Sweeney, C., Takahashi, T., Tilbrook, B., and Wanninkhof, R.: The reinvigoration of the Southern Ocean carbon sink, Science, 349, 1221-1224, 2015.

Laruelle, G. G., Durr, H. H., Lauerwald, R., Hartmann, J., Slomp, C. P., Goossens, N., and Regnier, P. A. G.: Global multi-scale segmentation of continental and coastal waters from the watersheds to the continental margins, Hydrol. Earth Syst. Sci., 17, 2029-2051, https://doi.org/10.5194/hess-17-2029-2013, 2013.

Laruelle, G. G., Lauerwald, R., Pfeil, B., and Regnier, P.: Regionalized global budget of the $\mathrm{CO}_{2}$ exchange at the air-water interface in continental shelf seas, Global Biogeochem. Cy., 28, 1199-1214, 2014. 
Laruelle, G. G., Lauerwald, R., Rotschi, J., Raymond, P. A., Hartmann, J., and Regnier, P.: Seasonal response of air-water $\mathrm{CO}_{2}$ exchange along the land-ocean aquatic continuum of the northeast North American coast, Biogeosciences, 12, 1447-1458, https://doi.org/10.5194/bg-12-1447-2015, 2015.

Laruelle, G. G., Landschützer, P., Gruber, N., Tison, J.-L., Delille, B., and Regnier, P.: Global high resolution monthly $p \mathrm{CO}_{2}$ climatology for the coastal ocean derived from neural network interpolation, Biogeosciences Discuss., https://doi.org/10.5194/bg2017-64, in review, 2017.

Lauerwald, R., Laruelle, G. G., Hartmann, J., Ciais, P., and Regnier, P. A. G.: Spatial patterns in $\mathrm{CO}_{2}$ evasion from the global river network, Global Biogeochem. Cy., 29, 534-554, 2015.

Le Quéré, C., Moriarty, R., Andrew, R. M., Canadell, J. G., Sitch, S., Korsbakken, J. I., Friedlingstein, P., Peters, G. P., Andres, R. J., Boden, T. A., Houghton, R. A., House, J. I., Keeling, R. F., Tans, P., Arneth, A., Bakker, D. C. E., Barbero, L., Bopp, L., Chang, J., Chevallier, F., Chini, L. P., Ciais, P., Fader, M., Feely, R. A., Gkritzalis, T., Harris, I., Hauck, J., Ilyina, T., Jain, A. K., Kato, E., Kitidis, V., Klein Goldewijk, K., Koven, C., Landschützer, P., Lauvset, S. K., Lefèvre, N., Lenton, A., Lima, I. D., Metzl, N., Millero, F., Munro, D. R., Murata, A., Nabel, J. E. M. S., Nakaoka, S., Nojiri, Y., O’Brien, K., Olsen, A., Ono, T., Pérez, F. F., Pfeil, B., Pierrot, D., Poulter, B., Rehder, G., Rödenbeck, C., Saito, S., Schuster, U., Schwinger, J., Séférian, R., Steinhoff, T., Stocker, B. D., Sutton, A. J., Takahashi, T., Tilbrook, B., van der Laan-Luijkx, I. T., van der Werf, G. R., van Heuven, S., Vandemark, D., Viovy, N., Wiltshire, A., Zaehle, S., and Zeng, N.: Global Carbon Budget 2015, Earth Syst. Sci. Data, 7, 349-396, https://doi.org/10.5194/essd-7-349-2015, 2015.

Lehner, B. and Döll, P.: Development and validation of a global database of lakes, reservoirs and wetlands, J. Hydrol., 296, 1-22, 2004

Lehner, B., Verdin, K., and Jarvis, A.: New Global Hydrography Derived From Spaceborne Elevation Data, EOS, 89, 93-94, 2008.

Lenton, A., Tilbrook, B., Law, R. M., Bakker, D., Doney, S. C., Gruber, N., Ishii, M., Hoppema, M., Lovenduski, N. S., Matear, R. J., McNeil, B. I., Metzl, N., Mikaloff Fletcher, S. E., Monteiro, P. M. S., Rödenbeck, C., Sweeney, C., and Takahashi, T.: Seaair $\mathrm{CO}_{2}$ fluxes in the Southern Ocean for the period 1990-2009, Biogeosciences, 10, 4037-4054, https://doi.org/10.5194/bg-104037-2013, 2013.

Luyssaert, S., Abril, G., Andres, R., Bastviken, D., Bellassen, V., Bergamaschi, P., Bousquet, P., Chevallier, F., Ciais, P., Corazza, M., Dechow, R., Erb, K. H., Etiope, G., Fortems-Cheiney, A., Grassi, G., Hartmann, J., Jung, M., Lathière, J., Lohila, A., Mayorga, E., Moosdorf, N., Njakou, D. S., Otto, J., Papale, D., Peters, W., Peylin, P., Raymond, P., Rödenbeck, C., Saarnio, S., Schulze, E. D., Szopa, S., Thompson, R., Verkerk, P. J., Vuichard, N., Wang, R., Wattenbach, M., and Zaehle, S.: The European land and inland water $\mathrm{CO}_{2}, \mathrm{CO}, \mathrm{CH}_{4}$ and $\mathrm{N}_{2} \mathrm{O}$ balance between 2001 and 2005, Biogeosciences, 9, 3357-3380, 2012.

Magnani, F., Mencuccini, M., Borghetti, M., Berbigier, P., Berninger, F., Delzon, S., Grelle, A., Hari, P., Jarvis, P. G., Kolari, P., Kowalski, A. S., Lankreijer, H., Law, B. E., Lindroth, A., Loustau, D., Manca, G., Moncrieff, J. B., Rayment, M., Tedeschi, V., Valentini, R., and Grace, J.: The human footprint in the car- bon cycle of temperate and boreal forests, Nature, 447, 848-850, 2007.

Malhi, Y., Phillips, O. L., Lloyd, J., Baker, T., Wright, J., Almeida, S., Arroyo, L., Frederiksen, T., Grace, J., Higuchi, N., Killeen, T., Laurance, W. F., Leano, C., Lewis, S., Meir, P., Monteagudo, A., Neill, D., Vargas, P. N., Panfil, S. N., Patino, S., Pitman, N., Quesada, C. A., Rudas-Ll, A., Salomao, R., Saleska, S., Silva, N., Silveira, M., Sombroek, W. G., Valencia, R., Martinez, R. V., Vieira, I. C. G., and Vinceti, B.: An international network to monitor the structure, composition and dynamics of Amazonian forests (RAINFOR), J. Veg. Sci., 13, 439-450, 2002.

Masarie, K. A. and Tans, P. P.: Extension and Integration of Atmospheric Carbon-Dioxide Data into a Globally Consistent Measurement Record, J. Geophys. Res.-Atmos., 100, 11593-11610, 1995.

Meybeck, M., Durr, H. H., and Vorosmarty, C. J.: Global coastal segmentation and its river catchment contributors: A new look at land-ocean linkage, Global Biogeochem. Cy., 20, GB1S90, https://doi.org/10.1029/2005GB002540, 2006.

Pan, Y., Birdsey, R. A., Fang, J., Houghton, R., Kauppi, P. E., Kurz, W. A., Phillips, O. L., Shvidenko, A., Lewis, S. L., Canadell, J. G., Ciais, P., Jackson, R. B., Pacala, S. W., McGuire, A. D., Piao, S., Rautiainen, A., Sitch, S., and Hayes, D.: A Large and Persistent Carbon Sink in the World's Forests, Science, 333, 988 993, 2011.

Patra, P. K., Canadell, J. G., Houghton, R. A., Piao, S. L., Oh, N. H., Ciais, P., Manjunath, K. R., Chhabra, A., Wang, T., Bhattacharya, T., Bousquet, P., Hartman, J., Ito, A., Mayorga, E., Niwa, Y., Raymond, P. A., Sarma, V. V. S. S., and Lasco, R.: The carbon budget of South Asia, Biogeosciences, 10, 513-527, https://doi.org/10.5194/bg-10-513-2013, 2013.

Peylin, P., Law, R. M., Gurney, K. R., Chevallier, F., Jacobson, A. R., Maki, T., Niwa, Y., Patra, P. K., Peters, W., Rayner, P. J., Rodenbeck, C., van der Laan-Luijkx, I. T., and Zhang, X.: Global atmospheric carbon budget: results from an ensemble of atmospheric $\mathrm{CO}_{2}$ inversions, Biogeosciences, 10, 6699-6720, https://doi.org/10.5194/bg-10-6699-2013, 2013.

Piao, S. L., Ito, A., Li, S. G., Huang, Y., Ciais, P., Wang, X. H., Peng, S. S., Nan, H. J., Zhao, C., Ahlström, A., Andres, R. J., Chevallier, F., Fang, J. Y., Hartmann, J., Huntingford, C., Jeong, S., Levis, S., Levy, P. E., Li, J. S., Lomas, M. R., Mao, J. F., Mayorga, E., Mohammat, A., Muraoka, H., Peng, C. H., Peylin, P., Poulter, B., Shen, Z. H., Shi, X., Sitch, S., Tao, S., Tian, H. Q., Wu, X. P., Xu, M., Yu, G. R., Viovy, N., Zaehle, S., Zeng, N., and Zhu, B.: The carbon budget of terrestrial ecosystems in East Asia over the last two decades, Biogeosciences, 9, 3571-3586, https://doi.org/10.5194/bg-9-3571-2012, 2012.

Pongratz, J., Reick, C. H., Raddatz, T., and Claussen, M.: Effects of anthropogenic land cover change on the carbon cycle of the last millennium, Global Biogeochem. Cy., 23, GB4001, https://doi.org/10.1029/2009GB003488, 2009.

Poulter, B.: Global Wood Harvest, Operational Global Carbon Observing System - GEOCARBON Project Report, 2015 (data available upon request).

Prather, M. J., Holmes, C. D., and Hsu, J.: Reactive greenhouse gas scenarios: Systematic exploration of uncertainties and the role of atmospheric chemistry, Geophys. Res. Lett., 39, L09803, https://doi.org/10.1029/2012GL051440, 2012. 
Randerson, J. T., Chen, Y., van der Werf, G. R., Rogers, B. M., and Morton, D. C.: Global burned area and biomass burning emissions from small fires, J. Geophys. Res., 117, G04012, https://doi.org/10.1029/2012JG002128, 2012.

Raupach, M. R., Rayner, P. J., Barrett, D. J., DeFries, R. S., Heimann, M., Ojima, D. S., Quegan, S., and Schmullius, C. C.: Model-data synthesis in terrestrial carbon observation: methods, data requirements and data uncertainty specifications, Glob. Change Biol., 11, 378-397, 2005.

Raymond, P. A., Hartmann, J., Lauerwald, R., Sobek, S., McDonald, C., Hoover, M., Butman, D., Striegl, R., Mayorga, E., Humborg, C., Kortelainen, P., Durr, H., Meybeck, M., Ciais, P., and Guth, P.: Global carbon dioxide emissions from inland waters, Nature, 503, 355-359, 2013.

Raymond, P. A., Zappa, C. J., Butman, D., Bott, T. L., Potter, J., Mulholland, P., Laursen, A. E., McDowell, W. H., and Newbold, D.: Scaling the gas transfer velocity and hydraulic geometry in streams and small rivers, Limnol. Oceanogr., 2, 41-53, 2012.

Rayner, P. J., Scholze, M., Knorr, W., Kaminski, T., Giering, R., and Widmann, H.: Two decades of terrestrial carbon fluxes from a carbon cycle data assimilation system (CCDAS), Global Biogeochem. Cy., 19, GB2026, https://doi.org/10.1029/2004GB002254, 2005.

Richey, J. E., Melack, J. M., Aufdenkampe, A. K., Ballester, V. M., and Hess, L. L.: Outgassing from Amazonian rivers and wetlands as a large tropical source of atmospheric $\mathrm{CO}_{2}$, Nature, 416, 617620, 2002.

Rödenbeck, C., Bakker, D. C. E., Gruber, N., Iida, Y., Jacobson, A. R., Jones, S., Landschützer, P., Metzl, N., Nakaoka, S., Olsen, A., Park, G. H., Peylin, P., Rodgers, K. B., Sasse, T. P., Schuster, U., Shutler, J. D., Valsala, V., Wanninkhof, R., and Zeng, J.: Data-based estimates of the ocean carbon sink variability first - results of the Surface Ocean $p \mathrm{CO}_{2}$ Mapping intercomparison (SOCOM), Biogeosciences, 12, 72517278, https://doi.org/10.5194/bg-12-7251-2015, 2015.

Rödenbeck, C., Bakker, D. C. E., Metzl, N., Olsen, A., Sabine, C., Cassar, N., Reum, F., Keeling, R. F., and Heimann, M.: Interannual sea-air $\mathrm{CO}_{2}$ flux variability from an observationdriven ocean mixed-layer scheme, Biogeosciences, 11, 45994613, https://doi.org/10.5194/bg-11-4599-2014, 2014.

Ruddiman, W. F.: The anthropogenic greenhouse era began thousands of years ago, Climatic Change, 61, 261-293, 2003.

Sarma, V. V. S. S., Lenton, A., Law, R. M., Metzl, N., Patra, P. K., Doney, S., Lima, I. D., Dlugokencky, E., Ramonet, M., and Valsala, V.: Sea-air $\mathrm{CO}_{2}$ fluxes in the Indian Ocean between 1990 and 2009, Biogeosciences, 10, 7035-7052, https://doi.org/10.5194/bg-10-7035-2013, 2013.

Schuster, U., McKinley, G. A., Bates, N., Chevallier, F., Doney, S. C., Fay, A. R., González-Dávila, M., Gruber, N., Jones, S., Krijnen, J., Landschützer, P., Lefèvre, N., Manizza, M., Mathis, J., Metzl, N., Olsen, A., Rios, A. F., Rödenbeck, C., Santana-Casiano, J. M., Takahashi, T., Wanninkhof, R., and Watson, A. J.: An assessment of the Atlantic and Arctic sea-air $\mathrm{CO}_{2}$ fluxes, 1990-2009, Biogeosciences, 10, 607-627, https://doi.org/10.5194/bg-10-607-2013, 2013.

Schwalm, C. R., Huntzinger, D. N., Fisher, J. B., Michalak, A. M., Bowman, K., Ciais, P., Cook, R., El-Masri, B., Hayes, D., Huang, M., Ito, A., Jain, A., King, A. W., Lei, H., Liu, J., Lu, C., Mao, J., Peng, S., Poulter, B., Ricciuto, D., Schaefer, K., Shi, X., Tao, B.,
Tian, H., Wang, W., Wei, Y., Yang, J., and Zeng, N.: Toward “optimal" integration of terrestrial biosphere models, Geophys. Res. Lett., 42, 4418-4428, https://doi.org/10.1002/2015GL064002, 2015.

Sindelarova, K., Granier, C., Bouarar, I., Guenther, A., Tilmes, S., Stavrakou, T., Muller, J. F., Kuhn, U., Stefani, P., and Knorr, W.: Global data set of biogenic VOC emissions calculated by the MEGAN model over the last 30 years, Atmos. Chem. Phys., 14, 9317-9341, https://doi.org/10.5194/acp-14-9317-2014, 2014.

Sitch, S., Friedlingstein, P., Gruber, N., Jones, S. D., MurrayTortarolo, G., Ahlström, A., Doney, S. C., Graven, H., Heinze, C., Huntingford, C., Levis, S., Levy, P. E., Lomas, M., Poulter, B., Viovy, N., Zaehle, S., Zeng, N., Arneth, A., Bonan, G., Bopp, L., Canadell, J. G., Chevallier, F., Ciais, P., Ellis, R., Gloor, M., Peylin, P., Piao, S. L., Le Quéré, C., Smith, B., Zhu, Z., and Myneni, R.: Recent trends and drivers of regional sources and sinks of carbon dioxide, Biogeosciences, 12, 653679, https://doi.org/10.5194/bg-12-653-2015, 2015.

Takahashi, T., Sutherland, S. C., Wanninkhof, R., Sweeney, C., Feely, R. A., Chipman, D. W., Hales, B., Friederich, G., Chavez, F., Sabine, C., Watson, A., Bakker, D. C. E., Schuster, U., Metzl, N., Yoshikawa-Inoue, H., Ishii, M., Midorikawa, T., Nojiri, Y., Kortzinger, A., Steinhoff, T., Hoppema, M., Olafsson, J., Arnarson, T. S., Tilbrook, B., Johannessen, T., Olsen, A., Bellerby, R., Wong, C. S., Delille, B., Bates, N. R., and de Baar, H. J. W.: Climatological mean and decadal change in surface ocean $p \mathrm{CO}_{2}$, and net sea-air $\mathrm{CO}_{2}$ flux over the global oceans, Deep-Sea Res. Pt. I, 56, 2075-2076, 2009.

Tatem, A. J., Goetz, S. J., and Hay, S. I.: Fifty years of earthobservation satellites - Views from space have led to countless advances on the ground in both scientific knowledge and daily life, Am. Sci., 96, 390-398, 2008.

Tramontana, G., Jung, M., Schwalm, C. R., Ichii, K., Camps-Valls, G., Ráduly, B., Reichstein, M., Arain, M. A., Cescatti, A., Kiely, G., Merbold, L., Serrano-Ortiz, P., Sickert, S., Wolf, S., and Papale, D.: Predicting carbon dioxide and energy fluxes across global FLUXNET sites with regression algorithms, Biogeosciences, 13, 4291-4313, https://doi.org/10.5194/bg-13-42912016, 2016.

Trumbore, S.: Carbon respired by terrestrial ecosystems -recent progress and challenges, Glob. Change Biol., 12, 141-153, 2006.

Tyukavina, A., Baccini, A., Hansen, M. C., Potapov, P. V., Stehman, S. V., Houghton, R. A., Krylov, A. M., Turubanova, S., and Goetz, S. J.: Aboveground carbon loss in natural and managed tropical forests from 2000 to 2012, Environ. Res. Lett., 10, 074002, https://doi.org/10.1088/1748-9326/10/7/074002, 2015.

UNFCCC: $\quad$ http://www4.unfccc.int/Submissions/INDC/ SubmissionPages/submissions.aspx (last accessed: 25 July 2017), 2015.

Valentini, R., Arneth, A., Bombelli, A., Castaldi, S., Cazzolla Gatti, R., Chevallier, F., Ciais, P., Grieco, E., Hartmann, J., Henry, M., Houghton, R. A., Jung, M., Kutsch, W. L., Malhi, Y., Mayorga, E., Merbold, L., Murray-Tortarolo, G., Papale, D., Peylin, P., Poulter, B., Raymond, P. A., Santini, M., Sitch, S., Vaglio Laurin, G., van der Werf, G. R., Williams, C. A., and Scholes, R. J.: A full greenhouse gases budget of Africa: synthesis, uncertainties, and vulnerabilities, Biogeosciences, 11, 381-407, https://doi.org/10.5194/bg-11-381-2014, 2014. 
van der Werf, G. R., Randerson, J. T., Giglio, L., Collatz, G. J., Mu, M., Kasibhatla, P. S., Morton, D. C., DeFries, R. S., Jin, Y., and van Leeuwen, T. T.: Global fire emissions and the contribution of deforestation, savanna, forest, agricultural, and peat fires (1997-2009), Atmos. Chem. Phys., 10, 11707-11735, https://doi.org/10.5194/acp-10-11707-2010, 2010.

van der Werf, G. R., Randerson, J. T., Giglio, L., van Leeuwen, T. T., Chen, Y., Rogers, B. M., Mu, M., van Marle, M. J. E., Morton, D. C., Collatz, G. J., Yokelson, R. J., and Kasibhatla, P. S.: Global fire emissions estimates during 1997-2015, Earth Syst. Sci. Data Discuss., https://doi.org/10.5194/essd-2016-62, accepted, 2017.

Vernadsky, V.: The Biosphere (New York: Copernicus, Springer), 1926.

Wanninkhof, R.: Relationship between wind speed and gas exchange over the ocean, J. Geophys. Res.-Ocean., 97, 7373-7382, 1992.

Wanninkhof, R., Park, G. H., Takahashi, T., Sweeney, C., Feely, R., Nojiri, Y., Gruber, N., Doney, S. C., McKinley, G. A., Lenton, A., Le Quéré, C., Heinze, C., Schwinger, J., Graven, H., and Khatiwala, S.: Global ocean carbon uptake: magnitude, variability and trends, Biogeosciences, 10, 1983-2000, https://doi.org/10.5194/bg-10-1983-2013, 2013..
West, T. O., Bandaru, V., Brandt, C. C., Schuh, A. E., and Ogle, S. M.: Regional uptake and release of crop carbon in the United States, Biogeosciences, 8, 2037-2046, https://doi.org/10.5194/bg-8-2037-2011, 2011.

Wolf, J., West, T. O., Le Page, Y. L., Kyle, G. P., Zhang, X., Collatz, G. J., and Imhoff, M. L.: Biogenic carbon fluxes from global agricultural production and consumption, Global Biogeochem. Cy., https://doi.org/10.1002/2015GB005119, 2015a.

Wolf, J., West, T. O., Le Page, Y. L., Kyle, G. P., Zhang, X., Collatz, G. J., and Imhoff, M. L.: CMS: Carbon Fluxes from Global Agricultural Production and Consumption, 2005-2011, ORNL DAAC, Oak Ridge, Tennessee, USA, 2015b.

Zhou, L. M., Tian, Y. H., Myneni, R. B., Ciais, P., Saatchi, S., Liu, Y. Y., Piao, S. L., Chen, H. S., Vermote, E. F., Song, C. H., and Hwang, T. H.: Widespread decline of Congo rainforest greenness in the past decade, Nature, 509, 86-90, 2014. 